\title{
Articles
}

\section{The Diversity of the EU Approach to Law Enforcement- Towards a Coherent Model Inspired by a Law and Economics Approach}

\author{
By Michael Faure \& Franziska Weber ${ }^{*}$
}

\begin{abstract}
Traditionally in the division of labor between the European level and the Member States it was, roughly, the European legislature that set the norms and the Member States that took care of enforcing these norms. In various policy areas, an implementation deficit has been observed, which is said to be partly due to the Member States facing difficulties with the choice of procedural options. For that reason, among others, the European legislature increasingly prescribes the enforcement approach to the Member States to back up national legislation that implements European law. This Article examines the incoherence of the EU's approach to law enforcement in the areas of consumer, competition, environmental, and insider trading laws. After setting out the EU's legal competences with a view to law enforcement, the rather diverse picture-mixes-of private, administrative, and criminal law enforcement in the four areas will be illustrated. The authors then ask the question of whether this divergence can be explained by an economic reasoning with respect to law enforcement. The analysis, however, identifies substantial differences between an ideal enforcement mix and the current enforcement approaches used in EU law. Moreover, it is suggested that the economic approach could be employed to provide more consistency to the use of enforcement tools in EU law.
\end{abstract}

\footnotetext{
${ }^{*}$ M.G. Faure - University of Maastricht Faculty of Law, Metro, Maastricht, the Netherlands, Erasmus University Rotterdam - Erasmus School of Law, Rotterdam, the Netherlands. Email: michael.faure@maastrichtuniversity.nl. F. Weber; University of Hamburg - Faculty of Law, Hamburg, Germany. Email: franziska.weber@uni-hamburg.de. We are grateful to Jan Przerwa (Maastricht University) and Merle Linn (Hamburg University) for editorial assistance and to Graham Sedgley for linguistic corrections.
} 


\section{A. Introduction}

Traditionally in the division of labor between the European level and the Member States (MS) it was, roughly, the European legislature that set the norms and the MS that took care of enforcing the norms that were set at the European Union (EU) level. In some domains, the EU takes care of enforcement itself. This is, for example, the case in the European competition law domain. ${ }^{1}$ But in most policy domains-consumer protection, insider trading, and environmental protection-the EU needs to rely upon the collaboration of the MS to implement and transpose European legislation into national law and to enforce its provisions, be it, for example, prohibitions of unfair commercial practices or product safety standards. In various policy areas an implementation deficit has been observed, which is said to be partly due to the MS facing difficulties with the choice of procedural options. ${ }^{2}$ For that reason, the European legislature increasingly prescribes the enforcement approach to the MS to back up national legislation that implements European law. This paper examines the incoherence of the EU's approach to law enforcement.

One cannot help but notice that the enforcement tools used and prescribed in various policy areas differ significantly, including elements of private law enforcement, criminal law enforcement, etc. In the domain of insider trading and in the environmental area, the Union legislature, for example, attempts to use criminal law. In other domains, such as competition law, the EU legislature-on the contrary-relies on administrative enforcement and encourages the use of private enforcement, but is against the criminalization of breaches of European competition law. The consumer law domain provides a different mixed picture with a recent emphasis on public law enforcement. As already mentioned, in some areaspredominantly competition law-the Commission acts as a direct enforcer itself.

There is no such thing as a specific formal legislative competence for the EU legislature with a view to law enforcement. ${ }^{3}$ Hence, the legislature is not limited in choosing a particular enforcement strategy. The goal of our paper is to examine in more detail the EU's strategies that have been followed with respect to the enforcement policy in different sectors, and to display the different approaches. We will analyze the enforcement approaches in specific areas and question the coherence of the motivations given by the EU Commission for choosing the particular strategy. In order to enable a rigorous analysis, we will rely on a

\footnotetext{
${ }^{1}$ Roger Van den Bergh \& Peter Camesasca, European Competition Law and Economics: A Comparative Perspective 158-59 (2001).

${ }^{2}$ See Directorate General for Internal Policies, Tools for ensuring the implementation and application of EU law and evaluation of their effectiveness (2013), 17, http://www.europarl.europa.eu/RegData/etudes/etudes/join/2013/493014/IPOL-JURI_ET\%282013\%29493014_EN.pdf (last visited Feb. 6, 2016) (noting the alternative label "compliance deficit").

${ }^{3}$ For a discussion of (private) EU law enforcement before a court, see generally Volkert Wilman, Private Enforcement of EU Law Before National Courts. The EU Legislative Framework (2015).
} 
consistent framework regarding the adequate enforcement measures which were developed by law and economics. The law and economics literature has addressed in a rather detailed manner what the comparative benefits are of private and public law enforcement. Regarding public law enforcement, it distinguishes between administrative and criminal enforcement. We will analyze the main lessons from this literature to find out whether there are good reasons to apply different enforcement tools to the different policy areas-consumer, competition, environment, and insider trading. We will examine the approaches taken in the four policy areas against a law and economics perspective to disentangle incoherencies. We choose to use law and economics not least because the EU institutions themselves are eager to refer to concepts of effectiveness and efficiency. ${ }^{4}$

Meanwhile, the scope of European law has been considerably expanded, which is why it is virtually impossible to address all areas. We have, therefore, selected four particular areas: Two areas where the Commission relies strongly on public enforcement, even through criminalization-insider trading and environmental law-and two areas where the situation is more mixed and where, in addition to public law, private law enforcement also plays an important role-consumer law ${ }^{5}$ and competition law. ${ }^{6}$

The remainder of the Article is structured as follows: Section B covers the legal competences of the EU regarding law enforcement will be analyzed; Section C follows with an illustration of the various approaches taken in different areas. Next Section D analyzes law and economics arguments for when the different enforcement mechanisms are effective, which results in an enforcement matrix indicating the optimal mix between private, administrative and public law enforcement. Section $E$ then applies the enforcement matrix to the four policy areas to enable an assessment of where the EU lacks coherence in its approach with a view to these scientifically established findings. Section F concludes the Article.

\footnotetext{
${ }^{4}$ See, e.g., the works of the European Commission for the Efficiency of Justice (CEPEJ); Art. 83(2) TFEU is all about ensuring the effectiveness of EU legislation which may justify the need for criminal enforcement.

${ }^{5}$ The consumer protection field has recently shown some elements of public law enforcement, however, including discussions on collective redress and alternative dispute resolution as an enhancement of the prevailing private enforcement.

${ }^{6}$ Essentially, the traditional enforcement approach is based on administrative law, but complementing it with private law enforcement is a new development.
} 


\section{B. The EU's Legislative Competences in Law Enforcement}

The essence of the supra-national nature of European Law is illustrated by the fact that MS have transferred some legislative competences to the EU and thereby limited their own sovereign rights to adopt legislation in the areas in question. ${ }^{7}$ The scope of such EU competences differs as to various legal fields.

Traditionally and for many years, the European legislature has abstained from prescribing the law enforcement provisions while harmonizing substantive laws throughout the EU. The so-called procedural autonomy of MS was respected. ${ }^{8}$ Article 67 (1) TFEU, establishes a European area of freedom, justice and security, and respects the different legal systems and traditions of the MS in particular areas-such as procedural law-which are well established at the national level while being rather new at the EU level. This approach, however, has been increasingly softened lately. ${ }^{9}$ One crucial justification is the previously mentioned "implementation deficit" of EU law that the Commission observes. ${ }^{10}$ Of course, the primary means to act against implementation deficits is for the Commission to open an infringement proceeding according to Article 258 TFEU against a MS. Due to limited capacity, however, the European legislature directly impacts $\mathrm{MS}^{\prime}$ enforcement tools through legislation. There is no such thing as a specific competence for law enforcement. The EU has very clearly set out its competences for legislating matters regarding criminal penalties. With a view to the EU's competences in criminal law since the Lisbon Treaty, Article 83(2) TFEU provides Union competence to impose criminal penalties, it reads:

If the approximation of criminal laws and regulations of the MS proves essential to ensure the effective implementation of a Union policy in an area which has been subject to harmonization measures, directives may establish minimum rules with regard to the definition of criminal offences and sanctions in the area concerned. Such directives shall be adopted by the same ordinary or special legislative procedure as was followed for the adoption of the harmonization measures in question, without prejudice to Article 76.

\footnotetext{
${ }^{7}$ See Case 26/62, Van Genden Loos v. Netherlands Inland Revenue Administration, EU:C:1963:1; 1 C.M.L.R. (1970).

${ }^{8}$ See generally Wilman, supra note 3, at 394 (discussing the EU's involvement in enforcement).

${ }^{9}$ See Fabrizio Cafaggi \& Hans-W. Micklitz, New Frontiers of Consumer Protection: The Interplay Between Private and Public Enforcement 401, 404 (Fabrizio Cafaggi \& Hans-W. Micklitz eds., 2009).

${ }^{10}$ See Directorate General for Internal Policies (2013).
} 
Considering the events leading up to this insertion, a landmark decision needs mentioningCommission v. Council of September 13, 2005. Before that judgment, it was in fact doubtful whether the European legislature could force MS via directives to use criminal law. The Court of Justice judgment of September 13, 2005 in case C-176/03 changed this view. The Court argued that although:

[A]s a general rule, neither criminal law nor the rules of criminal procedure fall within the community competence... the last-mentioned finding does not prevent the community legislature, when the application of effective, proportionate and dissuasive criminal penalties by the competent national authorities is an essential measure for combating serious environmental offences, from taking measures which relate to the criminal law of the MS which it considers necessary in order to ensure that the rules which it lays down on environmental protection are fully effective. ${ }^{11}$

With that decision, it was made clear that within the conditions set by the decision of September 13, 2005 the Commission may prescribe the use of criminal penalties if the necessity conditions are fulfilled and the matter falls within its sphere of competence. The $\mathrm{EU}$ is, however, clearly not competent to "determine the type and level of the criminal penalties to be applied." 12 These new powers have, even before the entry-into-force of the Lisbon Treaty, already been used in the so-called Environmental Crime Directive of November 19, 2008 and the Ship Source Pollution Directive of October 21, 2009, which will both be discussed in further detail below.

Today's Treaty requires a test of whether criminal law measures are "essential" to achieve the goal of effective policy implementation. According to the communication, this test requires that the Commission carries out an assessment of the national enforcement regimes in place-based on clear factual evidence ${ }^{13}$-and of the added value of common EU minimum criminal law standards-taking into account the principles of necessity, proportionality, ${ }^{14}$ and subsidiarity. In this communication, market abuse is the first policy

\footnotetext{
${ }^{11}$ Case C-176/03, Comm'n v. Council, 2005 E.C.R. 542, para. 48.

${ }^{12}$ See Michael Faure, The Continental Story of Environmental Criminal Law in Europe after 23 October 2007, 17 EUR. ENERGY \& ENVTL. L. 68-75 (2008).

${ }^{13}$ The clear factual evidence should relate to the nature or effects of the crime and to a diverging legal situation in all MS, which could be problematic for the effective enforcement of an EU Policy subject to enforcement. These proofs preferably should be statistical data allowing assessment of the factual situation.

${ }^{14}$ The Institutions must establish a test of whether criminal law measures are "essential" to achieve the goal of an effective policy implementation. It implies that the legislatures need to analyze whether measures other than
} 
area cited amongst the ones for which EU criminal law is desirable. Once the need for criminal law is established, the concrete criminal measure to be adopted at the EU level needs to be identified. EU criminal law can require MS to take effective, proportionate, and dissuasive criminal sanctions for a specific conduct. The Commission's interpretation of "minimum rules" is clear: Several documents specify that "EU law sometimes specifically determines which types and/or levels of criminal sanctions are to be made applicable." ${ }^{15}$ In each case, the EU instrument may only set out which sanctions must "at least" be made available to the judges in each MS. ${ }^{16}$

By Article 83 of the Treaty, EU legislation is limited to "minimum" rules on criminal law. Consequently, full harmonization is impossible. Moreover, Article 83(2) TFEU mentions that the objective is to reach an "approximation of criminal laws and regulations of the MS," meaning a reduction of the degree of variation between the national systems. ${ }^{17}$ Nevertheless, according to the principles of legal certainty and proportionality, it is important to clearly define what conduct may be considered criminal, as well as the result

criminal law measures could not sufficiently ensure the policy implementation and whether criminal law could address the problem more effectively. See Communication From the Commission to the European Parliament, The Council, The European and Social Committee and the Committee of the Regions, at 7, COM (2011) 573 final (Sept. 20, 2011). Moreover, the condition of necessity applies to the level of deciding which criminal law measures to include in a particular legislative instrument. Art. 49 of the Charter of Fundamental Rights "the severity of the penalty must not be disproportionate to the criminal offence" applies here; Communication From the Commission to the European Parliament, The Council, The European and Social Committee and the Committee of the Regions, at 8, COM (2011) 573 final (Sept. 20, 2011). See also Marc Groenhuijsen \& Jannemieke W. Ouwerkerk, Utima ratio en criteria voor strafbaarstelling in Europees perspectief, in Roosacthing strafrecht. Liber Amicorum Theo de Roos (Marc S. Groenhuijsen, Tijs Kooijmans \& Jannemieke W. Ouwerkerk eds, 2013).

${ }^{15}$ The possibility of making a proposal in the field of criminal law including the type and level of criminal sanctions

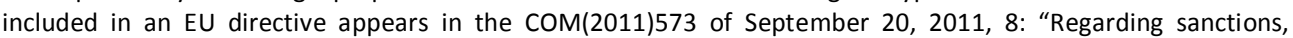
'minimum rules' can be requirements of certain sanction types (e.g. fines, imprisonment, disqualification), levels or the EU-wide definition of what are to be considered aggravating or mitigating circumstances"; It also appears in the Communication of the Commission on reinforcing sanctioning regimes in the financial services sector, $\operatorname{COM}(2010)$ 716 final of December 8, 2010, 14: "Any proposals in the field of criminal law should aim at ensuring appropriate coherence and consistency across different sectors, in particular when considering the type and level of criminal sanctions included in EU directives"; The European Commission page dedicated to the criminal law policy also specifies that "The EU can adopt directives providing for minimum rules regarding the definitions of criminal offences, for example, rules setting out which behavior is considered to constitute a criminal act and which type and level of sanctions are applicable for such acts", http://ec.europa.eu/justice/criminal/criminal-law-policy/ (last visited February 13, 2016). Most recently, Directive 2014/57/EU on criminal sanctions for market abuse June 12, 2004 (OJ L 173/179) (which entered force on July 3, 2014) now explicitly prescribes a maximum term of imprisonment and Regulation No 596/2014 of June 12, 2014 (OJ L 173/1) provides for mandatory "administrative measures and sanctions."

${ }^{16}$ Towards an EU Criminal Policy: Ensuring the Effective Implementation of EU Policies Through Criminal Law, COM (2011) 573, at 8-9.

${ }^{17} / d$. at 9 . 
to be achieved through the implementation of EU legislation. The concept of "minimum" rules would gain from clarification to avoid any ambiguity. ${ }^{18}$

In summary, a rather detailed account has been taken of the Union legislature's powers to introduce criminal sanctions in the MS for certain violations of EU law. The article may be applied with a view to any area which has been subject to harmonization measures. ${ }^{19}$ So, for such cases it applies in a horizontal fashion. Nothing comparably specific has, however, been said about the use of administrative or private enforcement.

One needs to acknowledge that even if the EU legislature prescribes criminal law as such, the details of criminal law enforcement may still differ according to the systems prevalent in the different MS-for example, investigative powers available. Even if not stipulated in the treaties or in secondary legislation, the CJEU has developed further indications on the EU's approach to law enforcement. Whenever MS remain free in the choice of instruments for the implementation of a legal act and ensuring its enforcement, case law holds that these sanctions in the case of a violation of implementing legislation should at least be effective, proportional, and dissuasive. ${ }^{20}$ This formulation can be found back in many directives that require MS to provide sanctions, which are indeed "effective, proportionate and dissuasive." ${ }^{21}$ Case law also establishes that the lack of effective prosecution against violators of implementing legislation can be considered a violation of European law. ${ }^{22}$ Hence,

${ }^{18}$ See Samuli Miettinen, Criminal Law and Policy in the European Union 44ff. (2012)

\begin{abstract}
The choice of instruments and their inherent limits will also remain a point of contention. Express provisions on approximation refer to directives as the legal instrument by which the Union may create minimum rules. Given substantial limitations to the Directive as an instrument, and to the potential lack of direct effect on instruments containing minimum rules, the question arises whether any provisions on the new Area of Freedom, Security and Justice (AFSJ) may allow directly applicable rules on criminal law to be created in the form of Regulation, or whether either these or other competences ostensibly outside the AFSJ can be exercised to circumvent AFSJ references to directives. If the narrative on the development of EU criminal competences can be seen as a contest between the centralizing effects of EU law and the desire of the Member States to retain criminal law as a relatively de-centralized policy area, then Lisbon has changed the rules but has not ended the game. What, for example, are 'minimum rules'?
\end{abstract}

${ }^{19}$ See Art. 83(2) TFEU.

${ }^{20}$ See Case C-68/88, Commission v. Greece, 1989 E.C.R. 339 para. 24.

${ }^{21}$ This is also the formula used in Art. 5 of Directive 2008/99/EC of November 19, 2008 on the protection of the environment through criminal law, December 6, 2008, O.J. (L 328) 28, p. 28-37.

${ }^{22}$ Case C-265/95, Commission v. France, 1997 E.C.R. 595 paras. $52 \mathrm{ff}$. 
Europe is increasingly referring to the requirement to provide effective remedies to cope with the implementation deficit. Article 19 (1) II TEU, furthermore, puts the responsibility on the MS to "providing remedies sufficient to ensure effective legal protection in the fields covered by Union law." 23

In essence, a body of guidelines has been developed that can be labeled the "enforcement principle." ${ }^{24}$ The CJEU has developed the requirement of effectiveness of EU law as a general legal principle. ${ }^{25}$ In the early case law it was left to the MS to determine how the interests of an individual adversely affected by an infringement of EU law were to be protected reflecting the principal of national procedural autonomy. Consequently, the principles of practical possibility and non-discrimination/equivalence were introduced with regard to the remedy that national law would specify. The court therefore started taking a stronger stance even in areas where EU law did not foresee specific rules by referring among others to the principles of proportionality, adequacy, and effective judicial protection. ${ }^{26}$ Sometimes the CJEU imposed remedies, such as in the case Metallgesellschaft \& Hoechst in which it left it to the national court to classify the nature of an action brought, whether as an action for restitution or an action for compensatory damages. ${ }^{27}$ Similarly, in competition law the court was quite explicit regarding the remedy. For example, in the Manfredi ruling it clarified that the injured party must be able to seek compensation not only for actual loss, but also for loss of profit. ${ }^{28}$ Other procedural aspects that CJEU case-law has explicitly touched upon are limitation periods, rules of evidence, and access to court. ${ }^{29}$ In addition to the court rulings, we shall set out how the EU legislation in our selected fields has occasionally gone even further than requiring MS to make certain remedies available, and has suggested, for example, which players were to be empowered to enforce a certain aspect of EU consumer or competition law.

\footnotetext{
${ }^{23}$ This can be regarded as a principle in the sense of Art. 52(2).

${ }^{24}$ See Gerhard Wagner, Private Law Enforcement Through ADR: Wonder Drug or Snake Oil, 51 COMMON MKT. L. REV. 165, 168 (2014) (On p. 169 Wagner speaks of a "triad of effectiveness, proportionality and dissuasiveness-or deterrence").

${ }^{25}$ See Paul Craig \& Gráinne de Búrca, Text, Cases and Materials 218 (6th ed. 2015).

${ }^{26}$ See id. at 218.

${ }^{27}$ Case C-410/98, Metallgesellschaft \& Hoechst v. Inland Revenue, 2001 E.C.R. 134.

${ }^{28}$ Case C-295-298/04 Manfredi v. Lloyd Adriatico Assicurazioni SpA et al, 2006 E.C.R. 461, para. 95; later confirmed in Case C-536/11, Bundeswettbewerbsbehörde v. Donau Chemie AG and Others, 2013 E.C.R. 366, para 24.

${ }^{29}$ See Craig \& de Burca, supra note 25 at 218 et seq. This is also true with a view to Directive 2013/0185 (COD) of the European Parliament and of the Council on certain rules governing actions for damages under national law for infringements of the competition law provisions of the Member States and of the European Union. That Directive will be discussed under 3.2 .
} 
In essence, the $\mathrm{EU}$ is increasingly intervening in the $\mathrm{MS}^{\prime}$ enforcement domain and the Lisbon Treaty specifically stipulates a legislative competence to require criminal law enforcement. In the next section, we will illustrate the enforcement approaches used in four selected policy areas in more detail. Thereby, we will identify the extent to which the general competences have been used. ${ }^{30}$

\section{Law Enforcement Instruments Divided by Policy Areas}

In this Section, we will address how European law-making initiatives approach the enforcement mix. We will focus on the enforcement approaches used in consumer law, competition law, environmental law, and insider trading. For each policy domain, we will first examine to what extent private enforcement is used in the particular policy area; we will equally address to what extent steps have been taken to strengthen private enforcement-for example, stimulating alternative dispute resolution (ADR) or collective redress. Next, we will examine to what extent public enforcement is used and whether within public enforcement there is a focus on administrative or criminal law. After sketching the enforcement mixes in the four domains under consideration, we will conclude by pointing out the incoherence of the approach in the different areas.

\section{Enforcement of European Consumer Law}

\section{Respecting Varying National Traditions}

In the area of EU consumer protection law, enforcement is entirely in the hands of the MS. The Commission has no direct enforcement powers in relation to economic operators who infringe EU law and it cannot assess individual cases between consumers and particular traders. MS traditions with a view to the enforcement of consumer law are varied. Some MS traditionally follow public and others private law enforcement models. ${ }^{31} \mathrm{~A}$ minority of countries, for example in Austria and Germany, strongly emphasize private law enforcement. Scandinavian countries have a public law enforcement tradition. All jurisdictions provide for a system of individual consumer claims before the civil courts. The

\footnotetext{
${ }^{30}$ We are obviously aware of the fact that there are many more provisions in EU law dealing with law enforcement. In that respect, we can, for example, refer to article 47 of the EU Charter of Fundamental Rights, providing a right to an effective remedy and to a fair trial, but also for example to Council Regulation No 44/2001 on jurisdiction, recognition and enforcement of judgments in civil and commercial matters-also known as Brussels I. The latter instruments are obviously of importance as well, but they are not advocated as enforcement instruments for specific domains by the EU legislature, but rather as tools guaranteeing an effective access to justice for EU citizens and they do not specifically address the implementation and enforcement of particular policy domains. Consequently, those instruments remain outside of this paper's scope.

${ }^{31}$ See Roger Van den Bergh, Should Consumer Protection Law Be Publicly Enforced?: An Economic Perspective on EC Regulation 2006/2004 and its Implementation in the Consumer Protection Laws of the Member States, in COLLECTIVE ENFORCEMENT OF CONSUMER LAW 179, $180 \mathrm{ff}$ (Willem van Boom \& Marco Loos eds., 2007).
} 
EU legislature has always respected the different traditions, but more recently has shown a preference for some public law enforcement.

Various directives in the field of consumer law in the past show awareness of the different enforcement traditions in the MS by leaving the choice of the enforcement mechanisms to the MS. Article 11 on the Enforcement in the Unfair Commercial Practices Directive, ${ }^{32}$ for example, leaves it to the MS whether to guarantee the enforcement by "courts or administrative authorities," paying tribute to their respective public or private law enforcement traditions. ${ }^{33}$ The general competence to legislate such consumer matters is justified by Article 153 TEC-now in essence Articles 12 and 169 TFEU-according to which the EU is to attain a high level of consumer protection and by Article 95 TEC-now Article 114 TFEU - the so-called harmonization clause. ${ }^{34}$ National laws were found to be divergent and, hence, capable of hindering cross-border trade. In fact, recital 2 of the Directive refers to Article 14(2) TEC-now Article 26 TFEU-and asserts that the Directive's content is "vital for the promotion of the development of cross-border activities." This reflects the justifications given in the extended impact assessment. ${ }^{35}$ Similarly, the Unfair Contract Terms Directive, ${ }^{36}$ which stems from a time when impact assessments were not yet used, refers in its recitals to the internal market and consumer protection objectives. It quotes Article 100a TEC-now Article 114 TFEU - which concerns the approximation of MS laws and mentions the objective of achieving a well-functioning internal market and a high level of consumer protection.

European legislation is pertinent when it comes to remedy injunctive relief in the collective context. ${ }^{37} \mathrm{~A}$ qualified body can bring an injunction for infringements of national provisions implementing the EU Directives-for example, consumer credit, package travel etc. According to recital 5:

\footnotetext{
32 Directive 2005/29/EC of the European Parliament and the Council of May 11, 2005 concerning unfair businessto-consumer commercial practices in the internal market and amending Council Directive 84/450/EEC, Directives 97/7/EC, 98/27/EC and 2002/65/EC of the European Parliament and of the Council and Regulation (EC) No 2006/2004 of the European Parliament and of the Council, June 11, 2005, OJ L 149/22.

${ }^{33}$ See also Council Directive 90/314/EEC of June 13, 1990 (highlighting other directives that leave the design of enforcement options open and in this case with package travel, package holidays and package tours); Council Directive 93/13/EEC of April 5, 1993 (explaining unfair terms in consumer contracts).

${ }^{34}$ Recital 1. ex Art. 100a TEC pre-Amsterdam became (ex) Art. 95 TEC post-Amsterdam and is now Art. 114 TFEU.

${ }^{35}$ Commission staff working paper on the extended impact assessment of the Directive of the European Parliament and of the Council concerning unfair business-to-consumer commercial practices in the Internal Market and amending Directives 84/450/EEC, 97/7/EC and 98/27/EC (the Unfair Commercial Practices Directive), 10.

${ }^{36}$ See the Council Directive 93/13, of April 5, 1993, on unfair terms in consumer contracts, 1993, OJ L 95/29.

${ }^{37}$ Directive 98/27, of May 19, 1998 on injunctions for the protection of consumers' interests, June 11, 1998, OJ L $166(\mathrm{EC})$.
} 


\begin{abstract}
Whereas one option should consist of requiring one or more independent public bodies, specifically responsible for the protection of the collective interests of consumers, to exercise the rights of action set out in this Directive; whereas another option should provide for the exercise of those rights by organizations whose purpose is to protect the collective interests of consumers, in accordance with criteria laid down by national law. ${ }^{38}$
\end{abstract}

Thus, this Directive shows awareness of the fact that some MS have strong consumer associations and others strong public bodies. Again, it stems from the period when impact assessments were not common. This Directive refers to Article 100a TEC-now Article 114 TFEU.

The controversial Consumer Rights Directive needs mentioning. ${ }^{39}$ Notably when the Directive was adopted by the European Parliament on June 23, 2011, its most controversial aspect-namely the full harmonization approach-had been significantly mitigated. According to Article 23(2), enforcement action can be undertaken by three different groups: Public bodies or their representatives, consumer organizations having a legitimate interest in protecting consumers, and professional organizations having a legitimate interest in acting. One or more of those bodies may act before the courts or the competent administrative bodies. Hence, this Directive again leaves scope to accommodate the varying MS preferences. MS need to ensure that "adequate and effective means exist to ensure compliance with this Directive" - see Article 23(1). Article 24, furthermore, paraphrases the notion developed in case-law that "Member States shall lay down the rules on penalties applicable to infringements of the national provisions adopted pursuant to this Directive and shall take all measures necessary to ensure that they are implemented. The penalties provided for must be effective, proportionate and dissuasive." Hence, the nature of the remedy is specified but the means to achieving it are left to the MS. The legal basis, again, is Article 114 TFEU. The impact assessment refers to the fragmentation of consumer laws in the MS due to the minimum harmonization approaches in different consumer law directives. ${ }^{40}$ It also refers to a lack of coordination in the EU regulatory framework regarding consumer law.

\footnotetext{
${ }^{38}$ See also Article 3 of the Directive.

${ }^{39}$ Directive 2011/83, of 25 October 2011 on consumer rights, 2011, OJ (L 304) 64 (EEC).

${ }^{40}$ See Commission Staff Working Document accompanying the proposal for a directive on consumer rights Impact Assessment Report, 2.
} 


\section{Public Enforcement}

A change-in the sense that the EU legislature took a stronger stance on the desirable enforcement mechanisms for certain consumer law problems-started happening subtly with the process of the accession of Central and Eastern European countries to the EU, which led to almost all accession candidates establishing a public authority. ${ }^{41}$ As set out in the 1995 Commission White paper on the Preparation of the Associated Countries of CEE for Integration into the Internal Market of the Union, ${ }^{42}$ the EU required allocating a "general and horizontal competence on consumer affairs to one designated authority." In terms of accession to the EU, public agencies were attractive candidates for both sides as it was a visible way of showing compliance and commitment on the one hand and being a "preferred interlocutor and partner" of the European Commission. ${ }^{43}$ The EU legislature's preference for public enforcement in Regulation 2006/2004 on consumer protection cooperation-CPC Regulation-ties in with this trend. ${ }^{44}$ The preparatory works reveal a preference for a public regulator..$^{45} \mathrm{~A}$ particular advantage is seen in the possibility of public authorities to act ex ante. The regulation applies only to certain cross-border infringements. Prior to this legislation, MS lacked the ability to carry out investigations in another MS. ${ }^{46}$ The CPC Regulation creates an EU-wide network of national enforcement authorities with similar investigation and enforcement powers. This meant that MS, where such an authority did not exist, had to establish one and at least equip it with a minimum of powers. ${ }^{47}$ Its legal basis is once more Article 95 TEC-now Article 114 TFEU. The CPC network has recently been internally and externally evaluated. The Commission report of 2014 discusses, among other

\footnotetext{
${ }^{41}$ Except for the Czech and Slovak Republics' public enforcement was recognized as an indispensable element of the overall institutional framework of consumer protection in all CEE countries.

${ }^{42} \operatorname{COM}(1995) 163$ final (May 10, 1995).

${ }^{43}$ See Antonina Bakardijeva Engelbrekt, Public and Private Enforcement of Consumer Law, in Central and Eastern Europe: Institutional Choice in the Shadow of EU Enlargement, in New Frontiers of Consumer Protection-the Interplay Between Private and Public Enforcement 91, 109 (Fabrizio Cafaggi \& Hans-W. Micklitz eds., 2009).

${ }^{44}$ Council Regulation 2006/2004, of the European Parliament and of the Council of October 27, 2004 on Cooperation Between National Authorities Responsible for the Enforcement of Consumer Protection Laws (the Regulation on consumer protection cooperation). Text with EEA relevance, 9.12.2004, OJ (L 364), 1-11.

${ }^{45}$ See Green Paper on European Union Consumer Protection, at 17, COM (2001) 531 final (Oct. 2, 2001). The Green Paper on EU Consumer Protection identified a gap in the enforcement of consumer protection laws relating to consumer economic interests in the internal market. It stressed the ability of public authorities to act to prevent consumer detriment before it happens. The green paper is said to have been triggering a broad consensus among stakeholders.

${ }^{46}$ Recital 2, CPC Regulation.

${ }^{47}$ See Jules Stuyck, Public and Private Enforcement in Consumer Protection: General Comparison EU-USA, in New Frontiers of Consumer Protection - the Interplay between Private and Public Enforcement 63, 79 (Fabrizio Cafaggi \& Hans-W. Micklitzeds eds., 2009).
} 
findings, an enhancement of investigative powers, such as the power to carry out test purchases, to name infringing traders, to request penalty payments, to recover illicitly obtained gains, or to obtain interim measures. ${ }^{48}$ Another topic is a more active role for the Commission itself in the context of the CPC network. ${ }^{49}$

\section{Private Enforcement}

With a view to enhancing the private law enforcement dimension, the EU has acted on Alternative Dispute Resolution (ADR) - starting with the Recommendation 98/257/EC which sets out minimum quality guarantees for all parties involved. ${ }^{50}$ Importantly, unlike the current situation in the EU, it provides for full coverage of ADR bodies for every sector, which MS had to implement by $2015 .{ }^{51}$ Again, Article 114 TFEU is specifically mentioned. ${ }^{52}$ All ADR entities have to meet quality criteria in line with the requirements set out in the Directive. It is, however, being stated in recital 21 that "the directive should be without prejudice to the form which ADR procedures take in the Member States." It still leaves some discretion regarding the specific form of ADR to be implemented in the MS. Consequently, with this legislative document the EU clearly strengthens ADR solutions in consumer law enforcement. Hence, this can be regarded as a furthering private law enforcement. Again, a clear stance is taken regarding the desirable enforcement mechanisms, restricting MS' $^{\prime}$ choice, both in the cross-border context, and even going further than previous legislation, in the national context.

${ }^{48}$ Commission Report on the Functioning of the CPC Cooperation, at 11, COM (2014) 439 (July 2014) ("Report on the functioning of Regulation (EC) No 2006/2004 of the European Parliament and of the Council of October 27, 2004 on cooperation between national authorities responsible for the enforcement of consumer protection laws (the Regulation on consumer protection cooperation).") In this light a new legislative proposal for a Regulation of the European Parliament and of the Council on cooperation between national authorities responsible for the enforcement of consumer protection laws, $\operatorname{COM}(2016) 283$ final $(25.05 .2016)$ was published by the European Commission.

${ }^{49} / d$. at 6 , referring to p. iii and pp. $45-48$ of Public consultation summary.

50 This was adopted together with a Regulation on Online Dispute Resolution. See Directive 2013/11, of the European Parliament and of the Council of May 21, 2013 on alternative dispute resolution for consumer disputes and amending Regulation (EC) No. 2006/2004 and Directive 2009/22/EC, OJ (L 165) 63 of June 18, 2013 (Directive on Consumer ADR) and Regulation (EU) No 524/2013 of the European Parliament and of the Council of 21 May 2013 on online dispute resolution for consumer disputes, OJ L 165/1 of June 18, 2013 (Regulation on Consumer ODR).

${ }^{51}$ With the exception of health and education.

52 See for an extensive impact assessment: COM (2011) 793 (Nov. 29, 2011), SEC (2011) 1409 final (Nov. 29, 2011), COMMISSION STAFF WORKING PAPER IMPACT ASSESSMENT Accompanying the document Proposal for a Directive of the European Parliament and of the Council on Alternative Dispute Resolution for consumer disputes (Directive on consumer ADR) and Proposal for a Regulation of the European Parliament and of the Council on Online Dispute Resolution for consumer disputes (Regulation on consumer ADR). 
Previously the EU legislature had passed a mediation Directive. ${ }^{53}$ With the European Small Claims Procedure ${ }^{54}$ and the European Payment Order ${ }^{55}$ it, furthermore, sought to enhance the private law enforcement dimension of European consumer law in the cross-border context. A new regulation of 2015 which updates these two procedures is, by the way, based upon Article 81 TFEU as it has only a cross-border dimension. ${ }^{56}$ The mediation Directive is based upon the articles which preceded Article 81 TFEU. ${ }^{57}$

Legislative action in the area of collective actions is likewise being discussed..$^{58}$ In the EU, "collective action" is defined as a possibility for "many similar legal claims to be bundled into a single court action." ${ }^{59}$ It refers to both injunctive relief and compensatory relief. Legislative action in the field of collective actions was first discussed in two fields separately: In consumer law by DG SANCO and in competition law by DG COMP. ${ }^{60}$ Then DG JUST merged these initiatives were in order to contribute considerations from the perspective of the harmonization of civil procedure. ${ }^{61}$ Recently, the EU has issued the following documents: A

${ }^{53}$ Directive 2008/52 of the European Parliament and of the Council of May 21, 2008 on certain aspects of mediation in civil and commercial matters, May 24, 2008, O.J. (L 136), 3-8 (EC).

${ }^{54}$ Commission Regulation No. 861/2007 of the European Parliament and of the Council of July 11, 2007 establishing a European Small Claims Procedure, O.J. (L 199), 1-22; recently amended by Regulation (EU) 2015/2421 of the European Parliament and of the Council of 16 December 2015 amending Regulation (EC) No 861/2007 establishing a European Small Claims Procedure and Regulation (EC) No 1896/2006 creating a European order for payment procedure, O.J. (L 341), 1-13.

${ }^{55}$ Regulation (EC) No 1896/2006 of the European Parliament and of the Council of December 12, 2006 created a European order for payment procedure, O.J. (L 399), 1-32; likewise, recently amended by Regulation (EU) 2015/2421 of the European Parliament and of the Council of 16 December 2015 amending Regulation (EC) No. $861 / 2007$ establishing a European Small Claims Procedure and Regulation (EC) No. 1896/2006 creating a European order for payment procedure, O.J. (L 341), 1-13.

${ }^{56}$ See Regulation (EU) 2015/2421 of the European Parliament and of the Council of 16 December 2015 amending Regulation (EC) No. 861/2007 establishing a European Small Claims Procedure and Regulation (EC) No. 1896/2006 creating a European order for payment procedure, OJ (L 341), 1-13.

${ }^{57}$ Also, a legal aid directive (Council Directive 2002/8/EC of January 27, 2003 to improve access to justice in crossborder disputes by establishing minimum common rules relating to legal aid for such disputes OJ EC 2003L 26/41, corrigendum OJ EC 2003L 32/15) in the light of its pure application to the cross-border context was justified this way.

${ }^{58}$ See for the status quo of the process: http://ec.europa.eu/consumers/redress_cons/collective_redress_en.htm (last visited February 13, 2016).

${ }^{59}$ Commission Communication, 4.

60 Documents produced during this time entail: A Commission Green Paper on anti-trust actions, (COM (2005) 672 (Dec. 9, 2005)); a White Paper in 2008 (COM (2008) 165 (April 2, 2008)). In 2008, the Commission also published a Green Paper on consumer collective redress (COM (2008) 794 (Nov. 27, 2008)).

${ }^{61}$ See Christopher Hodges, Collective Redress: A Breakthrough or a Damp Squib?, 37 J. CONSUMER POL'Y 67, 68 (2013). 
Commission communication, ${ }^{62}$ which summarizes the debates on collective redress in response to the European Parliament's 2012 Resolution, ${ }^{63}$ and the Commission's recommendation. ${ }^{64}$ The Commission's recommendation states that all MS have national collective redress systems based on a number of common European principles. This recommendation applies to the field of consumer law, competition law, and more broadly. According to its recital 7:

Amongst those areas where the supplementary private enforcement of rights granted under Union law in the form of collective redress is of value, are consumer protection, competition, environment protection, protection of personal data, financial services legislation and investor protection. The principles set out in this Recommendation should be applied horizontally and equally in those areas but also in any other areas where collective claims for injunctions or damages in respect of violations of the rights granted under Union law would be relevant.

Importantly "representative action" in the definition of the Commission's Recommendation means:

An action which is brought by a representative entity, an ad hoc certified entity or a public authority on behalf of, and in the name of, two or more natural or legal persons who claim to be exposed to the risk of suffering harm or to have been harmed in a mass harm situation whereas those persons are not parties to the proceedings. ${ }^{65}$

\footnotetext{
62 Towards a European Horizontal Framework for Collective Redress, COM (2013) 3539/3 (June 12, 2013) “Towards a European Horizontal Framework for Collective Redress".

${ }^{63}$ European Parliament Resolution of February 2, 2012 "Towards a Coherent European Approach to Collective Redress", 2011/2089(INI).

${ }^{64}$ Commission Recommendation of June 11, 2013 on common principles for injunctive and compensatory collective redress mechanisms in the Member States concerning violations of rights granted under Union law, 2013 O.J. (L 201) 60 .

${ }^{65}$ See II 3(d) of the Recommendation.
} 
Consequently, it allows for any kind of representative. Clearly, differentiating between the public and private law dimension becomes a bigger challenge in such contexts of group litigation.

\section{Summary}

Overall, in consumer law it is argued that the traditional lines of public and private law enforcement have been broken up to some extent and that the procedural autonomy of the MS is in fact on the "countermarch." ${ }^{66}$ This development towards strengthening both private and public enforcement in the consumer domain has been happening for more than a decade. ${ }^{67} \mathrm{It}$ is only to some extent related to European integration; this development has also taken place independently of European norms describing it.

So, if one were to summarize the main tendencies concerning the European enforcement approach towards consumer law, one could reasonably consider that: (1) There is some reliance on private enforcement by stimulating a representative action by a private entity and putting some emphasis on ADR and mediation as a furtherance of private law enforcement in the broadest sense. Each MS has a civil justice system that allows individuals to sue for damages in private actions. ${ }^{68}$ Mass litigation to seek compensation is not a given in every MS, and actions for injunctive relief are more common. Seeking injunctions has been enabled by European legislation; (2) there is also a tendency to recommend public law enforcement, clearly with the CPC regulation for cross-border cases. Extensions of the investigative powers for such public authorities are, for example, discussed. Regarding collective redress, any representative, which could also be a public authority, is to be empowered as envisaged in the recommendation. European legislation has been less explicit regarding the appropriate remedy. Some of the legal documents, however, repeat the effectiveness requirements as developed in the CJEU case-law; (3) although the established authorities do have the capacity to request to cease an infringement under the penalty of a fine, ${ }^{69}$ these rules neither explicitly concern administrative sanctions nor give any mention of criminalization. In consumer law a mixed approach is, therefore, prevalent; and (4) some development can be observed whereby the EU legislature increasingly dictates the

\footnotetext{
${ }^{66}$ Fabrizio Cafaggi \& Hans.-W. Micklitz, Administrative and Judicial Enforcement in Consumer Protection: The Way Forward, in New Frontiers of Consumer Protection-the Interplay between Private and Public Enforcement 401 (Fabrizio Cafaggi \& Hans-W. Micklitzeds eds., 2009).

67 Ianika N. Tzankova \& Martin A. Gramatikov, A Critical Note on Two EU Principles: A Proceduralist View on the Draft CFR, in The Foundations of European Private Law 421 (Roger Brownsword, Hans-W. Micklitz, Leone Niglia \& Stephen Weatherill eds., 2011).

${ }^{68}$ See generally Mass Justice. Challenges of Representation and Distribution (Jenny Steele \& Willem van Boom eds., 2011) (commenting on private damage actions in the Member States) and MASS TORTS IN EUROPE. CASES AND REFLECTIONS (Willem van Boom \& Gerhard Wagner eds., 2014); see also Wilman, supra note 3, at 146-92.

${ }^{69}$ See Article 4 CPC Regulation.
} 
enforcement response rather than leaving MS with a choice. In consumer law, we see how Article 114 TFEU is used extensively to justify Union legislation. According to Articles 12 and 169 TFEU, the Union is to contribute to the attainment of a high level of consumer protection by the measures it adopts pursuant to Article 114 TFEU. Indeed, impact assessments are now complementing the legislative process.

\section{Enforcement of European Competition Law}

\section{Public Enforcement}

Unlike in consumer law, within competition law the European Commission also acts as a direct enforcer and does not for all cases rely on the MS level. European competition law is traditionally enforced by public authorities, such as the European Commission, or national competition authorities ${ }^{70}$ and, more recently, private parties, such as competitors, purchasers, and consumers. ${ }^{71}$ The main implementing regulation was Regulation No $17 .{ }^{72}$ Currently Article 103 of the TFEU gives the European Council powers to put in place an enforcement system, including the imposition of fines. Council Regulation 1/2003 gives the Commission powers to enforce these rules and to fine companies for infringements. ${ }^{73} \mathrm{It}$, furthermore, regulates the interplay between the public regulators and the courts with a view to competition law enforcement. The EU enforcement system of competition law is by and large traditionally based on imposing fines on companies to which the violation can be imputed. Recently the European Commission published a proposal for a Directive that is supposed to strengthen the effectiveness of the national competition authorities. ${ }^{74}$

\footnotetext{
${ }^{70}$ Competition Law and Policy in the EU and UK 80ff (5th edn, Barry J. Rodger \& Angus MacCulloch eds, 2015).

${ }^{71}$ See Roger Van den Bergh, Private Enforcement of European Competition Law and the Persisting Collective Action Problem, 12 MAASTRICHT J. OF EUR. \& COMP. L. 12 (2013).

72 Regulation No. 17 of February 6, 1962, OJ L 13/204. For further details, see Wouter P.J. Wils, The Optimal Enforcement of EC Antitrust Law. Essays in Law and Economics, Diss. Utrecht University, 8-9 (2002).

${ }^{73}$ Regulation No 1/2003 which replaced the mentioned Regulation No 17 (which had identical provisions on fines), January 4, 2003, OJ L 1 .

${ }^{74}$ Proposal for a Directive of the European Parliament and of the Council to empower the competition authorities of the Member States to be more effective enforcers and to ensure the proper functioning of the internal market, COM/2017/0142 final - 2017/063 (COD).
} 


\section{Private Enforcement}

Private compensation claims have been introduced to EU law in the CJEU case-law and recently been codified within a Directive on anti-trust damages actions. ${ }^{75}$ The case-law development started in 1974 and argued for the first time that today's Article 101(1) and 102 TFEU have a direct effect between private individuals. ${ }^{76}$ In the landmark judgment of 2001, in Courage v. Crehan, ${ }^{77}$ the CJEU held that victims of infringements of EU competition law have a right to compensation. The principle was further enshrined in later CJEU caselaw. ${ }^{78}$ The Directive stipulates an entitlement to full compensation, Article 3 , to anyonesuch as direct and indirect purchasers, consumers, umbrella plaintiffs-who suffered harm due to an infringement of competition law. Victims should obtain compensation for the harm suffered, which covers compensation for actual loss and for loss of profit, and in addition to payment of interest from the time the harm occurred until compensation is paid. ${ }^{79}$ It explicitly excludes any form of punitive damages. ${ }^{80}$ The legal basis, according to the Directive, are Article 114 TFEU and Article 103 TFEU, which are instruments giving effect to the principles set out in Articles 101 and 102 TFEU. The Directive applies to all anti-trust damages, both individual and collective. In itself it does not set out any details regarding the design of collective redress mechanisms.

An important factor is that the Directive on anti-trust damage actions provides that the entity responsible for handling these claims is neither the Commission nor a national competition authority but the civil courts of the respective MS. ${ }^{81}$ The interplay between the different enforcers is regulated in the already mentioned Regulation No $1 / 2003 .{ }^{82}$ The

\footnotetext{
75 Directive 2014/104, on certain rules governing actions for damages under national law for infringements of the competition law provisions of the Member States and of the European Union, 2014, O.J. (L 349) 1. See Wilman, supra note 3, at 202-44.

${ }^{76}$ Case 127/73, Belgische Radio en Televisie and société belge des auteurs, compositeurs et éditeurs v. SV SABAM and NV Fonior, 1974 E.C.R. 25, p. 51, para 16; Case C-282/95, P Guérin Automobiles v. Comm'n, 1997 E.C.R. 159, para. 39.

${ }^{77}$ Case C-453/99, Courage Ltd. v. Bernard Crehan, Bernard Crehan v. Courage Ltd. and Others, 2001 E.C.R. 465.

${ }^{78}$ Case C-295/04, Manfredi, Case 199/11EuropeseGemeenschap v. Otis NV and Others, 2012 E.C.R. 684, para. 41; Case 536/11, Donau Chemie u. a., para. 21; Case C-557/12, Kone AG and Others v. ÖBB-Infrastruktur AG, 2014 E.C.R. 1317, para. 21.

${ }^{79}$ See Art. 3(2) of Directive 2014/104 EU.

${ }^{80}$ See Art. 3(3) of Directive 2014/104 EU.

${ }^{81}$ See Recital (3) preceding Directive 2014/104 (on antitrust damage actions) (holding that anyone can claim compensation before national courts for the harm caused to them by an infringement of Articles 101 and 102 TFEU (the basic articles concerning EU competition law)).

82 Council Regulation (EC) No 1/2003 of December 16, 2002 on the implementation of the rules on competition laid down in Arts. 81 and 82 of the Treaty (Text with EEA relevance), January 4, 2003, O.J. (L 1), 1-25.
} 
regulation marked a change from ex ante notification, to public authorities, to an ex post notification system by individual complaints. A decrease in the administrative enforcement dimension has, therefore, been expected ever since.

The starting point for drafting the antitrust damages Directive was the so-called Ashurst study of 2004 that acknowledges a lack of private damages claims in the MS despite the Courage judgment and sets out the reasons in detail. ${ }^{83}$ This meant that in most MS there were no working national provisions on private redress in competition cases. Consequently, in competition law, aside from strong public enforcement, emphasis is now put on private enforcement. This is regarded as necessary to ensure the full effectiveness of Articles 101 and 102 TFEU. ${ }^{84}$ Both dimensions interact to guarantee the "maximum effectiveness of the competition rules." 85

Given that the approach selected with a view to collective redress is a horizontal one, the suggestions from the Commission's recommendation-and communication-that have been referred to in the previous section are equally valid. Whereas both the green paper ${ }^{86}$ and the white paper of $2008^{87}$ consider the possibility of regulating matters of collective redress within the anti-trust damages Directive, the final version of the Directive does not include such provisions. This means that the competence to decide whether to introduce collective mechanisms and of what sort, is left with the MS; this covers, for example, claims by private associations, public authorities or groups of victims.

\section{Summary}

Like consumer law, competition law provides a mixed picture. In sum, one can hold that: (1) There is a strong reliance on enforcement by public competition authorities at national and European level; (2) within public enforcement there is, distinct from the consumer law field, a strong reliance upon administrative enforcement. Administrative fines are the primary enforcement tools. Criminalization of competition law infringements is explicitly rejected; (3) there is a modest layer of private enforcement, which plays an increasingly important role; (4) private enforcement powers as a result of Directive 2014/104 on anti-trust damage actions, and the preceding case-law, complement the prevailing public enforcement approach which, in contrast to the consumer law field, is not only carried out by national

${ }^{83}$ Ashurst, Study on the Conditions of Claims for Damages in the Case of Infringement of EC Competition Rules, http://ec.europa.eu/competition/antitrust/actionsdamages/economic_clean_en.pdf (last visited 13 February 2016). The study was not received without criticism.

${ }^{84}$ See Recital 3 of Directive 2014/104 EU.

${ }^{85}$ See Recital 6 of Directive 2014/104 EU.

${ }^{86}$ See COM(2005)672: Green Paper - Damages actions for breach of the EC antitrust rules (SEC(2005)1732).

${ }^{87}$ White Paper on Damages Actions for Breach of the EC anti-trust rules, 2008 COM 165 (April 2, 2008). 
public enforcers-national competition authorities-but also by the European Commission itself. The Directive on anti-trust damages clearly grants the right to full compensation by means of private law enforcement. Furthermore, punitive damages are excluded; (5) regarding collective redress, however, requirements are only expressed in the form of a "recommendation," which is general and not limited to the competition policy area. The situation in the different MS varies considerably on this matter. With a view to collective redress, it is equally valid, as with consumer law, that the representative could be anyonea public or a private player.

\section{Enforcement of European Environmental Law}

\section{Private Enforcement}

European environmental law also seems, to some extent, to represent a mixture of private and public enforcement with, however, a much stronger tendency towards the use of criminal law. As far as private enforcement is concerned, we can point to two documents being of relevance, the first being the Environmental Liability Directive (ELD), of which the scope is, however, rather limited; the second being the Aarhus Convention, which may increase possibilities for access to justice for victims of pollution.

The ELD distinguishes between two different liability regimes. ${ }^{88}$ For a limited set of occupational activities listed in Annex III, mostly agricultural and industrial activities, a strict liability regime applies. ${ }^{89}$ The fault regime applies to other occupational activities not listed in Annex III. ${ }^{90}$ The effectiveness of the ELD is, however, doubtful. The Directive only applies to a limited definition of damage. ${ }^{91}$ Personal injury is, for example, excluded from the scope of the Directive. Causation is not specifically regulated in the Directive ${ }^{92}$ and it does not regulate cost allocation in cases of multi-party causation either. ${ }^{93}$ Moreover, MS are free to introduce "the defense of having complied with the permit." ${ }^{14}$ This can substantially limit

\footnotetext{
${ }^{88}$ Directive 2004/35/CE Of The European Parliament and of The Council of April 21, 2004 on environmental liability with regard to the prevention and remedying of environmental damage; Report from the Commission of October 12, 2010 under Art. 14(2) of Directive 2004/35/EC on environmental liability with regard to the prevention and remedying of environmental damage [COM(2010)581 final-Not published in the Official Journal].

${ }^{89}$ Lucas Bergkamp \& Anke Van Bergeijk, Scope of the ELD Regime, in The EU Environmental Liability Directive: A Commentary 62 (Lucas Bergkamp \& Barbara Goldsmith eds., 2013).

90 See Jing Liu, Compensating Ecological Damage. Comparative and Economic Observations 268 (2013).

${ }^{91}$ See Bergkamp \& Van Bergeijk, supra note 89, at 55.

92 See id. at 70.

${ }^{93}$ Art. 9 of the ELD.

${ }^{94}$ Art. $8(4)(a)$ of the ELD.
} 
the exposure to liability of an operator. Also, the ELD did not introduce compulsory liability insurance but merely encouraged MS to take measures promoting the development of financial security instruments. ${ }^{95}$ Given those limitations the literature has strong doubts on the effectiveness of the ELD. ${ }^{96}$ It is also debatable to what extent the ELD constitutes an instrument of private enforcement. The Directive has a strong focus on action taken by public authorities both in preventive action ${ }^{97}$ and remedial action. ${ }^{98}$ It is the competent authority that should require that preventive or remedial measures are taken by the operator. Natural or legal persons affected by environmental damage cannot themselves, on the basis of the Directive, take action but only formulate a request for action to the competent authority. ${ }^{99}$ Some therefore hold that although the ELD uses terms that resemble a civil liability regime, it is in essence a public or administrative law regime. ${ }^{100}$ The crucial point is that the ELD does not provide individual victims with a right to bring a claim for damages or other remedies against the operator. ${ }^{101}$ Hence it is doubtful that the ELD constitutes a regime of private enforcement. At best one could hold that it has a mixed/hybrid character.

Another aspect of private enforcement relates to the EU implementation of the Aarhus Convention. Article 9 of the Aarhus Convention provides that, if particular conditions are met, access to information, public participation in decision-making, and access to justice in environmental matters have to be guaranteed. The EU has largely dealt with the first two pillars: Access to information and public participation. In 2003 two directives were promulgated that largely dealt with the access to information ${ }^{102}$ and with public participation. ${ }^{103}$ In the same year a third proposal was introduced ${ }^{104}$ directed at implementing the provisions of the Aarhus Convention related to the third pillar-access to

\footnotetext{
${ }^{95}$ Art. 14 of the ELD.

${ }^{96}$ Michael Faure \& Kristel De Smedt, The ELD's Effects in Practice, in The EU Environmental Liability Directive: A Commentary 299 (Lucas Bergkamp \& Barbara Goldsmith eds., 2013).

${ }^{97}$ Directive 2004/35, art. 5.

${ }^{98}$ Directive 2004/35, art. 6.

${ }^{99}$ Based on Directive 2004/35, art. 12.

${ }^{100}$ Edward Brans, Fundamentals of Liability for Environmental Harm under the ELD, in The EU Environmental Liability Directive: A Commentary 38 (Lucas Bergkamp \& Barbara Goldsmith eds., 2013).

${ }^{101} \mathrm{lbid}$.

${ }^{102}$ Access to information, Directive 2003/4/EC.

103 Public participation, Directive 2003/35/EC.

104 Proposal for a Directive of the European Parliament and of the Council on access to justice in environmental matters, 2003COM 624 (Oct. 24, 2003).
} 
justice. That proposal, however, led to strong opposition in some MS, as a result the Commission did not pursue the promulgation of that directive. ${ }^{105}$ Although recent case law holds that MS, and more particularly national courts, have a duty to interpret national law in accordance with the objectives laid down in Article 9(3) of the Aarhus Convention, ${ }^{106}$ there is not yet a generalized access to justice in environmental matters which would encourage private enforcement. ${ }^{107}$

\section{Criminal Enforcement}

As far as environmental law is concerned, the European Commission has clearly more faith in public enforcement and more particularly in criminal law. The initiative towards the criminalization of environmental law in fact dates back to a Convention on the protection of the environment through criminal law adopted by the Council of Europe on November 4, $1998 .{ }^{108}$ As mentioned above, ${ }^{109}$ as a result of evolutions in case law, the European legislature was awarded competences to force MS to prescribe criminal sanctions. In the environmental law area, this led to the adoption of two directives, one related to ship-source pollution and one to environmental crime, together referred to as the Environmental Crimes Directives. ${ }^{110}$

These Directives clearly demonstrate the belief on the part of the European Commission for the need of criminal law as an enforcement mechanism in this field. Consideration 3 in Directive 2008/99, in particular, explains that experience has shown existing systems of penalties have been insufficient for achieving compliance with environmental protection laws. Such compliance, so the text continues, can and should be strengthened by the availability of criminal penalties, which demonstrate social disapproval of a qualitatively different nature compared to administrative penalties or a compensation mechanism under civil law. Consideration 10 of the Directive requires MS to provide for criminal penalties in

\footnotetext{
105 See the study: Measures on access to justice in environmental matters (Article 9(3)), http://ec.europa.eu/environment/aarhus/study_access.htm (last visited February 13, 2016).

106 For a discussion of this case law, see Jan H. Jans \& Hans B. Vedder, European Environmental Law. After Lisbon 228 (4th ed., 2012) (holding that from the case law of the Court (inter alia in the Janecek, Trianel and Slovak Bears case) it follows that Art. 9(3) of the Aarhus Convention is applicable across the full breadth of European environmental law).

107 See Chris Backes, Michael Faure \& Fokke Fernhout, Legal Background, in Access to Justice in Environmental Matters 7, (Michael Faure \& Niels Philipsen eds., 2014).

${ }^{108}$ Convention on the protection of the environmental criminal law, Strasbourg November 4, 1998, European Treaty Series No. 172, also published in Michael Faure and Gunter Heine, Environmental Criminal Law in the European Union. Documentation of the Main Provisions with Introductions 397 (2000).

${ }^{109}$ See the evolution of the EU legislative competences in law enforcement sketched above in section B.

110 O.J. (L 255) 11 of September 30, 2005.
} 
their national legislation in respect of serious infringements of provisions of community law on the protection of the environment. The Directive does not, however, create obligations as regards criminal penalties for individual cases. The updated Directive 2009/123 concerning ship-source pollution follows a similar model, although it contains specific provisions concerning the liability of legal persons; Article 8 of the Directive requires that legal persons held liable for environmental offences be punished by effective, proportionate, and dissuasive penalties. ${ }^{111}$

\section{Summary}

When reviewing the area of environmental law one can notice some remarkable differences with the domain of competition policy which was mentioned above, and inter alia notice that: (1) in contrast with competition law and consumer law, enforcement of European environmental law works through criminal law. In its Articles 3 and 4 Directive 2008/99 stipulates various offenses which are consequently enforceable by criminal law. These include the illegal shipment of waste, trade in endangered species, or in ozone-depleting substances, significant damage to the environment caused by unlawful emissions to the air, water or soil, and the unlawful operation of dangerous activities among others; (2) one can equally notice that in the area of environmental law, there is some private enforcement, which is also potentially collective, ${ }^{112}$ but that the focus is much more on public enforcement and more particularly on criminalization; (3) the environmental crime directives are completely silent on the issue of administrative enforcement. This, however, plays an important role in the practice of the $\mathrm{MS} ;^{113}$ (4) the encouragement of private enforcement of individual claims in the environmental liability Directive is rather weak. The access to justice pillar of the Aarhus Convention has not yet been fully implemented into EU law; (5) the sole instrument of public enforcement of EU policy, at least at EU level, is thus the criminal law. Administrative fines are not discussed at the EU level.

\section{Enforcement of Insider Trading Laws}

It is striking that the enforcement of insider trading laws follows to a large extent the same philosophy as environmental law: No attempt whatsoever at EU level to stimulate private enforcement. The focus is rather on criminal law and to some extent on administrative

\footnotetext{
${ }^{111}$ See further on this directive, Michael Faure, The Environmental Crime Directive 2008/99/EC, EUR. J. OF CONSUMER L. 193 (2011).

112 To the extent that the Recommendation concerning collective redress likewise applies in the context of environmental policy. Note, however, that this is not binding.

${ }^{113}$ For an overview of administrative environmental law enforcement in a few Member States (the Flemish Region in Belgium, the Netherlands, Germany and the UK) see Michael Faure \& Katarina Svatikova, Criminal or Administrative law to Protect the Environment? Evidence from Western-Europe, 24(2) J. OF ENVTL. L. 253 (2012).
} 
enforcement in that the criminal law dimension builds upon the administrative law dimension.

\section{Private Enforcement}

As far as private enforcement is concerned, we can be brief: There are to our knowledge no specific initiatives at EU level to stimulate private enforcement of insider trading laws. ${ }^{114}$ The origin of the regulation of insider trading in the EU goes back to the Financial Action Service Plan (FASP). ${ }^{115}$ Following this Financial Action Service Plan, the so-called Market Abuse Directive (MAD) was issued in 2003. ${ }^{116}$ A later directive also provided specific implementation rules. ${ }^{117}$ Moreover, a European Security Committee (ESC) was created ${ }^{118}$ as well as the Committee of European Securities Regulators (CESR). ${ }^{119}$ Note that in this MADDirective 2003/6-there was no indication concerning private enforcement. As a result, legal doctrine held that MS are not obliged to adopt statutory regulations granting a right of compensation to the individual investors. ${ }^{120}$ So, the MAD leaves it to the discretion of the MS to organize private enforcement.

\footnotetext{
114 In the United States, insider trading is both a crime, which can be punished by monetary penalties and imprisonment, and also a civil offense. The public players also have competences, which could be classified as administrative. Overall, private enforcement seems to play a minor role only, see M. Ventoruzzo, Comparing Insider Trading in the United States and in the European Union: History and Recent Developments (May 26, 2014). European Corporate Governance Institute (ECGI) - Law Working Paper No. 257/2014; Bocconi Legal Studies Research Paper No. 2442049, p. 26, http://ssrn.com/abstract $=2442049$ or $<$ http://dx.doi.org/10.2139/ssrn.2442049.

115 Financial services: implementing the framework for financial markets: action plan, COM (1999) 232 (May 11, 1999).

${ }^{116}$ Commission Directive 2003/6/EC on insider dealing and market manipulation of January 28, 2003.

117 Directive 2003/124/EC, implementing Directive 2003/6/EC of the European Parliament and of the Council as regards the definition and public disclosure of inside information and the definition of market manipulation; Directive 2003/125/EC, implementing Directive 2003/6/EC of the European Parliament and of the Council as regards the fair presentation of investment recommendations and the disclosure of conflicts of interest; Directive 2004/72/EC, implementing Directive 2003/6/EC of the European Parliament and of the Council as regards accepted market practices; Regulation (EC) No 2273/2003 on Market Abuse.
}

${ }_{118}$ Commission Decision establishing the European Securities Committee, COM (2001) 1493 (June 6, 2001). The ESC is constituted of officials of Member States government and Commission officials.

${ }^{119}$ Commission Decision establishing the Committee of European Securities Regulators, COM (2001) 1501 (June 6, 2001). The CESR is constituted of representatives of Member States' national regulators and Commission representatives.

120 See Vassilios D. Tountopoulos, Market Abuse and Private Enforcement, 11(3) EUR. Company \& FIN. L. ReV. 297, 301(2014). 


\section{Administrative Enforcement}

Adopted in early 2003, the MAD introduced a comprehensive framework to tackle insider dealing and market manipulation practices. In order to ensure the enforcement of Directive 2003/6/EC, MS were required to implement appropriate administrative measures and sanctions. This requirement did not imply any consequences on MS' criminal dispositions. Nevertheless, according to the Commission, the current system did not achieve the effective protection of the financial markets ${ }^{121}$ as desired. In December 2010, the European Commission issued a communication on "Reinforcing sanctioning regimes in the financial services sector." 122 The European and Securities Market Authority (ESMA) ${ }^{123}$ replaced the Committee of European Securities Regulation on the January 1, 2011. ESMA's work on securities legislation aims at contributing to the development of a single rulebook in Europe by improving co-ordination and co-operation amongst securities regulators, as well as acting as an advisory group to assist the EU Commission. ESMA is in charge of issuing guidance on the common operation of the MAD.

On October 20, 2011, the Commission issued a set of two proposals to review the EU regime dealing with market abuse. The first aspect of this reform proposition consists of a proposal for a regulation, ${ }^{124}$ which basically replaces the MAD and incorporates major elements of the directives implementing it, cited here above. This proposal for a regulation suggests

\footnotetext{
121 Proposal for Directive on criminal sanctions for insider dealing and market manipulation, at 3, COM (2011) 654 (Oct. 20, 2011).

${ }^{122}$ Communication of the Commission on reinforcing sanctioning regimes in the financial services sector, COM (2010) 716 (Dec. 8, 2010).

${ }^{123}$ European Securities and Market Authorities, http://www.esma.europa.eu (last visited February 14, 2016).

124 Proposal for a Regulation of the European Parliament and of the Council on insider dealing and market manipulation (market abuse), COM (2011) 651 final (Oct. 20, 2011).
} 
modifications to the prohibition, to the supervisory $y^{125}$ and enforcement powers ${ }^{126}$ as well as to the administrative measures and sanctions $\mathrm{s}^{127}$, directly applicable by the MS. The Commission justified this choice with the fact that a regulation would be the most appropriate legal instrument to define the market abuse framework within the Union because it reduces the regulatory complexity related to the diversity of legislation across the

125 Two important modifications relate to the expansion of the scope of the prohibition on insider trading (and the definition of attempted market manipulation), See Proposal for a Regulation on market abuse, at 29:

(e) information not falling within paragraphs (a), (b), (c), or (d) relating to one or more issuers of financial instruments or to one or more financial instruments, which is not generally made available to the public, but which, if it were available to a reasonable investor, who regularly deals in the market and the financial instrument or a related spot commodity contract concerned, would be regarded by that person as relevant when deciding the terms on which transactions in the financial instrument or a related spot commodity contract should be effected.

The notions of "precise nature" and "significant effect on prices" relative to insider information in all the other paragraphs (a), (b), (c) and (d) are missing in this one. It, consequently, considerably extends the definition of inside information. Cf. Mathias Siems \& Matthijs Nelemans, The Reform of the EU Market Abuse Law: Revolution or Evolution, 19 THE MAASTRICHT J. OF EUR. \& COMP. L. 195 (2012).

${ }^{126}$ See Proposal for a Regulation on market abuse, at 39:

Regarding regulators power, the regulation introduces reporting of suspicious orders and OTC transactions; ensures access to data and telephone records of telecommunications operators to investigate and sanction market abuse, subject to a judicial warrant; ensures access to private premises to seize documents to investigate and sanction market abuse, subject to a judicial warrant; grants protection and incentives to whistleblowers.

Art. 19 "Obligation to cooperate," Art. 20 "Cooperation with third country": Cross-border cooperation will be reinforced.

127 See Proposal for a Regulation on market abuse, at 47: Chapter 5: "Administrative measures and sanctions", p. 47-48: One of the most revolutionary aspects of the proposal for a Regulation is that administrative measures and sanctions will be harmonized:

administrative pecuniary sanctions of up to twice the amount of the profits gained or losses avoided because of the breach where those can be determined . . . in respect of a natural person, administrative pecuniary sanctions of up to $€ 5,000,000 \ldots$ in respect of a legal person, administrative pecuniary sanctions of up to $10 \%$ of its total annual turnover in the preceding business year... Every administrative measure and sanction imposed for breach of this Regulation shall be published without undue delay, including at least information on the type and nature of the breach and the identity of persons responsible for it, unless such publication would seriously jeopardize the stability of financial markets. 
Union. Indeed, it would offer greater legal certainty for those subject to the legislation across the Union, introducing a harmonized set of core rules, thereby contributing to the functioning of the single market. ${ }^{128}$

\section{Criminal Enforcement}

In addition, on the basis of article 83(2) TFEU, the European Commission's proposition entails a directive on criminal sanctions, applicable to insider trading and market manipulation. The motivation is that today MS use divergent criminal measures to enforce the prohibition of insider trading. The Commission argues, like in the Environmental Crimes Directives, that only criminal law can demonstrate social disapproval of a qualitatively different nature, compared to administrative sanctions or compensation under civil law. ${ }^{129}$ One of the reasons for this legislative action at EU level was the increasing number of cases of market manipulation and market abuse. In some of those cases the legal consequences of the exercise of investigative and adjudicative jurisdiction by every single MS were far from clear. That justified the creation of a European framework. ${ }^{130}$

In essence, the Union legislature started to rely strongly on criminal law enforcement with the Directive on criminal sanctions for market abuse 2014/57 of June 12, 2014. ${ }^{131}$ This Directive stipulates now in Article 7 that the MS have to ensure that insider trading is punishable by a maximum term of imprisonment of at least four years. This Directive on criminal sanctions for market abuse was adopted on the basis of the new article 83(2) TFEU. The final version of Regulation 596/2014 was equally issued on June 12, 2014. ${ }^{132}$ It has in Chapter 5 an explicit reference to administrative measures and sanctions, including the necessity to impose maximum administrative pecuniary sanctions. ${ }^{133}$

\footnotetext{
${ }^{128}$ See Proposal for a Regulation on market abuse, at 5.

${ }^{129}$ Consideration (6) preceding the proposal for a directive of the European Parliament and of the Council on criminal sanctions for insider dealing and market manipulation, at 8, COM (2011) 654 final (Oct. 20, 2011).

${ }^{130}$ See for an analysis of market manipulation cases with Fortis Bank and with Barclays and the legal problems that resulted from that Michiel Luchtman \& John Vervaele, Enforcing the Market Abuse Regime: Towards an Integrated Model of Criminal and Administrative Law Enforcement in the European Union?, 5(2) NEW J. OF EUR. CRIM. L. 192 (2014).

131 (2014) O.J. (L 173) 179.

132 (2014) O.J. (L 173) 1.

133 See on the accumulation of administrative and criminal sanctions and the problem this entails Luchtman \& Vervaele, supra note 130, at 192ff Sarah Wilson, The New Market Abuse Regulation and Directive on Criminal Sanctions for Market Abuse: European Capital Markets Law and New Global Trends in Financial Crime Enforcement, 16 ERA FORUM 427, 440ff (2015).
} 
These developments are based on an extensive impact assessment carried out in $2011 .{ }^{134}$ In this document which evaluates various policy options, there is no mention of private law enforcement except for a reference to American law. ${ }^{135}$ The same is true for the 2010 consultation paper, which precedes and explains the choices in the impact assessment. ${ }^{136}$ Note, however, that although private enforcement is nowhere explicitly mentioned, some legal doctrine holds that the New Market Abuse Regulation may, by being directly applicable against individuals, create obligations that could also be enforced before civil courts. ${ }^{137}$ Because private enforcement is not, however, explicitly addressed at EU level-in contrast with the case of competition policy-it will be up to the national courts of the MS to determine the terms and conditions of such private enforcement. ${ }^{138}$ The Directive is meant to explicitly enhance the administrative law dimension, which, according to its recital 5 , has "proven to be insufficient to ensure compliance with the rules on preventing and fighting market abuse." 139

\section{Summary}

Summarizing, the enforcement tools proposed for insider trading, one can notice that:

(1) there is no mention whatsoever of stimulating private enforcement, as opposed to the domain of environmental law where there is at least a weak attempt; (2) administrative penalties are no longer considered sufficient and that criminalization is considered necessary. Directive 2014/57 justifies this by referring to the ineffective nature of administrative enforcement. ${ }^{140}$ Today there is a co-existence of both types of sanctions; (3) MS may extend their enforcement provisions also to private enforcement or keep up private enforcement systems that they have in place. The instruments issued at the EU level-the Directive and the Regulation-are silent on private enforcement.

\footnotetext{
${ }^{134}$ Commission Staff Working Paper, IMPACT ASSESSMENT Accompanying the document Proposal for a Regulation of the European Parliament and of the Council on insider dealing market manipulation (market abuse) and the Proposal for a Directive of the European Parliament and of the Council on criminal sanctions for insider dealing and market manipulation, SEC (2011) 1217 final (Oct. 20, 2011).

${ }^{135}$ Some stakeholders that expressed a preference for civil law enforcement are named only in footnote 140 (and 329,348 ) of the impact assessment.

136 Public consultation on a revision of the Market Abuse Directive (MAD), http://ec.europa.eu/internal_market/consultations/docs/2010/mad/consultation_paper.pdf (last visited February 14, 2016).

${ }^{137}$ See Tountopoulos, supra note 120 , at 327.

${ }^{138}$ Tountopoulos, supra note 120 , at 332 .

${ }^{139}$ Recital 5 of Directive 2014/57/EU.

${ }^{140}$ Directive 2014/57/EU of the European Parliament and of the Council of April 16, 2014 on criminal sanctions for market abuse (Market Abuse Directive).
} 


\section{Incoherence in the Different Areas}

Summarizing the European approach towards enforcement in the four domains, which have been discussed, one could draw the following table, of course realizing that here it mainly indicates on which issues the European approach, not the one in the MS, is most targeted. ${ }^{141}$

\begin{tabular}{|l|l|l|l|}
\hline & Private & Administrative & Criminal \\
\hline Consumer & $\begin{array}{l}\text { Yes } \\
\text { Injunctions } \\
\text { ADR/mediation }\end{array}$ & $\begin{array}{l}\text { Limited } \\
\text { Duty to create public authority in } \\
\text { specific context for cross-border } \\
\text { cases (CPC) }\end{array}$ & No \\
\hline Competition & $\begin{array}{l}\text { Yes } \\
\text { Directive }\end{array}$ & $\begin{array}{l}\text { Yes, strongly } \\
\text { Provisions on fines }\end{array}$ & No \\
\hline Environment & Limited (only ELD) & No & Yes \\
\hline Insider Trading & No & $\begin{array}{l}\text { Yes, system previously based on } \\
\text { administrative fines is kept in place } \\
\text { and criminal sanctions are added on } \\
\text { top }\end{array}$ & Yes \\
\hline
\end{tabular}

Table 1: Enforcement approaches in the EU.

This, necessarily simplified, overview shows that there is considerable divergence in the EU approach towards enforcement. This divergence becomes especially clear when addressing private enforcement. This is strongly present in the consumer law area and to be implemented in the competition law domain. Regarding consumer law, the main developments to strengthen private law enforcement are the Injunctions Directive and legislation that introduces ADR bodies. Developments that have not been discussed in detail for the cross-border context, furthermore, concern the Regulation of small claims and the European order for payment procedure. The traditions in the MS regarding consumer law enforcement are divergent. Some have traditionally relied on private law enforcement and others on public law enforcement. With the CPC regulation, a public law element was

${ }^{141}$ Thus, it cannot sufficiently consider specific nuances or details, such as proposals towards collective action (aiming at strengthening private enforcement) in some domains. Recall that the recommendation on collective redress has a horizontal character, but that it is non-binding. 
introduced in every MS independent of its tradition. This is, however, only true for a limited set of cross-border violations. The Commission saw a particular need because of the lack of possibilities of the national enforcers to investigate in other European MS and carry out ex ante monitoring and market surveillance. Possible extensions of the investigative powers, just as a more active role for the European Commission itself may be the content of future legislative proposals. The assessment of the CPC regulation and the new proposal it led to reveals that the public enforcement dimension is regarded as necessary and will most likely be enhanced.

The new Directive on anti-trust damage actions adds a codified provision on established case law for damage claims in competition law and concretizes it at the same time. On top of the previously favored administrative enforcement approach, a private law enforcement dimension is added. The reasons given include the need to ensure the effectiveness of competition law and the divergences at national level with regard to the private law enforcement dimension. No criminal law is desired, either in the competition or in the consumer law context.

In the environmental law area, private enforcement plays only a small role-through the ELD-and is not mentioned at all in the context of insider trading. The divergence is also clear in the domain of criminal law. There is, especially recently, a strong reliance on the criminal law in the domain of the environment and insider trading, where directives forcing the MS towards criminalization have been issued. On the other hand, criminalization is strongly rejected in the competition law area and finds no mention in the consumer law area. The public law approach concerning insider trading and environmental law differs in the sense that for insider trading the EU had originally introduced a system of administrative law enforcement. With the developments in 2014, the criminal law dimension was added. For environmental law as it stands there has been no previous base system of administrative law enforcement as suggested by the EU. Of course, still in the context of environmental law, individual MS do employ administrative sanctions. Last, the recommendation at the European level regarding the supply of "collective actions," no matter which form they ultimately take, either public or private enforcement, is relevant horizontally over all applicable policy areas. Given the non-binding character of the instrument, its impact is limited. The extent to which an enforcement landscape includes elements of collective redress-except for very limited fields such as injunctions in consumer cases-is entirely left to the discretion of the MS.

\section{Law and Economics of (European) Law Enforcement}

The overview of what the Union legislature has done in four domains with respect to law enforcement shows, with a large variety in the choice for private of public enforcement as well as, within public enforcement, concerning the choice between administrative and criminal sanctions. That raises the question of the comparative benefits of private, administrative, and criminal enforcement and whether these are the underlying reasons for 
the diversity. Law and economics has addressed the question of under what conditions a particular enforcement mechanism could provide better results.

In Section I, we will develop a theoretical framework by first indicating some of the crucial factors which, from an economic perspective, should determine the choice of the enforcement approach. Then in Section II, we focus more particularly on the trade-off between private and public enforcement and identify the economic criteria that indicate which enforcement system might be more effective in particular circumstances. Given the space constraints, arguments for and against group litigation can only be dealt with in a very preliminary manner. Importantly, group litigation can be designed in any way and thus enhance private or public enforcement or both. In Section III, within public enforcement, we focus on the question of whether in particular circumstances either administrative or criminal enforcement may be more warranted. In Section IV we then bring those criteria together in a matrix indicating in which set of circumstances a given type of sanctioningcivil, administrative, or criminal may be indicated.

Given the space limitations in this paper we limit ourselves to roughly indicating whether private, administrative, or criminal enforcement may under particular circumstances be indicated for particular violations in the specific fields concerned. ${ }^{142} \mathrm{~A}$ final comment concerns the language we will use: The term criminal law may not have the same meaning in all the MS. For the purpose of our analysis we shall assume that the typical criminal law remedies to be granted via a criminal procedure will be fines and imprisonment-but not compensation; in administrative law they will be injunctions and fines; in some cases remedies such as license revocation are obtainable. In a civil procedure, compensation and civil law injunctions will be the main remedies; no punitive damages or civil law fines are available. ${ }^{143}$ In Section E we will apply the enforcement matrix that we have developed based on the law and economics literature to the four specific case studies-consumer, competition, environmental, and insider trading. This will, therefore, allow us to provide indications on the optimal enforcement mix for the specific policy areas, which can then be compared to the EU enforcement approach in the same domains.

\footnotetext{
142 Obviously, it may be possible to have a much more nuanced approach, addressing, for example, whether enforcement either via a civil court or via an ADR body would be more indicated or, for example, addressing group litigation/collective action in detail. That would, however, for the purposes of this study go much too far and is moreover not needed immediately because we merely want to use our general framework to broadly test some of the differences in the European approach in law enforcement that we identified in the previous paper. For a more refined approach, equally incorporating group litigation, ADR and self-regulation see Franziska Weber, The Law and Economics of Enforcing European Consumer Law - A Comparative Analysis of Package Travel and Misleading Advertising (2014).

${ }^{143}$ Obviously, this would vary to some extent in the different European countries.
} 


\section{Criteria Affecting the Choice}

Several economic criteria in law and economics literature on enforcement have been identified as determining the strengths and weaknesses of different enforcement mechanisms. ${ }^{144}$ They concern individuals' incentives to initiate a law enforcement response, enforcers' incentives to carry out the delegated tasks in the enforcement system as desired by society, and administrative costs. Regarding the last category, administrative costs as the name suggests relate broadly speaking to costs incurred by administering the enforcement process. Overall, the underlying idea is that a well-designed enforcement response can induce compliant behavior ex ante. ${ }^{145}$

Different types of violations lead to different actors being motivated to take action. Whether they will do so, furthermore, depends on the kind of enforcement mechanism in place. Parties will not act if a "rational apathy" problem is prevalent. The rational individual will not act if costs outweigh the benefits, for instance when harm is very small and the investment to enforce the law is costly. ${ }^{146}$ If harm to the society is large and law enforcement desirable, for example in a case of small and widespread harm, no action may be taken because of a divergence between the individual and social incentive to sue. ${ }^{147}$ The victim may not even have a voice, the example, the environment-so-called "victimless crimes." On the other hand, there are cases in which instead of the suing party the defendant turns out to be the victim -the victim of a "frivolous lawsuit" that is not based on merits and socially not desirable. ${ }^{148} \mathrm{~A}$ frivolous case becomes particularly worrisome if a wrong decision is taken based on such a "frivolous lawsuit" or complaint. Error costs refer to courts taking mistaken decisions. ${ }^{149}$ It can likewise be extended to other bodies. Error costs can generally be divided into two groups. Error I costs are those that occur when an individual who is guilty might

\footnotetext{
${ }^{144}$ Steven Shavell, The Optimal Structure of Law Enforcement, 36 J. OF L. AND ECON. 255 (1993); Van den Bergh, supra note 31, at 179; Franziska Weber, The Law and Economics of Enforcing European Consumer Law (2014), at 33 et seq.

${ }^{145}$ Gary S. Becker, Crime and Punishment: An Economic Approach, 76 J. of Pol. Econ. 169, 172 et seq. (1968).

${ }^{146}$ See Van den Bergh, supra note 31, at 184.

${ }^{147}$ See William M. Landes \& Richard A. Posner, The Private Enforcement of Law, 4(1) J. LeGAL STUD. 1-6, 33 (1975).

148 See Andrea Renda et al, Making Antitrust Damages Actions More Effective in the EU: Welfare Impact and Potential Scenarios (2007), at 562.

149 See Richard Posner, An Economic Approach to Legal Procedure and Judicial Administration, in The Economic Structure of the Law: The Collected Economic Essays of Richard A. Posner 290, 291 (Francesco Parisi ed., 2000) (referring to system costs as 'direct costs' for operating the legal dispute-resolution machinery).
} 
mistakenly not be found liable for a "mistaken acquittal." ${ }^{150}$ Error II costs on the other hand occur if an innocent individual might mistakenly be found liable for a "mistaken conviction."

Another distortion concerns "free-riding" problems. This problem can occur if in certain situations, in which many victims suffer from a law infringement, but all gain as soon as one of them complains, it is efficient for everybody to wait for someone else to do so and then profit from the result. ${ }^{151}$ Other factors influence the individual's incentives to sue. On the one hand, it is the remedy that matters, for instance, the motivation stemming from the prospect of compensation or a recovery of lost profits. Remedies differ between enforcement mechanisms as they are structured today. On the other hand, it concerns enforcement mechanisms' potential to cure information asymmetries that may exist between the two parties in conflict. Information asymmetries can be an impediment to litigation, which, in turn, leads to-potential-wrongdoers not being induced to legally compliant behavior. The information asymmetry can manifest itself in a lack of information on the identity of the wrongdoer, which can result in low probabilities of detecting legal violations or convicting wrongdoers. It may concern other aspects for which evidence needs to be raised or certain aspects of the procedures. Different enforcement mechanisms provide for different investigative powers. Lastly, individuals may not intervene because they may fear retaliation. ${ }^{152}$

Whereas so far we have primarily been concerned with the effects that law enforcement bodies' design has on the incentives of individuals whose actions are necessary in initiating or refraining from law enforcement, another concern is the possible distortion of the law enforcer's incentives. Deviations from desired behavior are primarily discussed under the heading of "capture and principal agent situations": Capture is an incentive problem, meaning the exertion of influence on the public administration that leads to public officials pursuing the industries' interests. ${ }^{153}$ This concept can be expanded to other enforcers-for example, public prosecutors or ADR bodies. A weakness inherent in the client-lawyer

\footnotetext{
150 See A. Mitchell Polinsky \& Steven Shavell, The Theory of Public Enforcement of Law, in Handbook of Law and Economics 405, 427 et seq. (Vol. 1, A. Mitchell Polinsky \& Steven Shavell, 2007).

${ }^{151}$ See Roger Van den Bergh \& Louis Visscher, Optimal Enforcement of Safety Law, in Mitigating Risk in the Context of Safety and Security. How Relevant is a Rational Approach? 14 (Richard V. de Mulder ed., 2008); Landes \& Posner, supra note 147, at 29.

152 See Shavell, supra note 144 , at 268 .

153 See Anthony Ogus, Regulation: Legal Form and Economic Theory 57 (1994); Christopher Hood, Henry Rothstein \& Robert Baldwin, The Government of Risk: Understanding Risk Regulation Regimes, 112 (1st ed. 2001); Nuno Garoupa \& Fernando Gomez-Pomar, Punish Once or Punish Twice: A Theory of the Use of Criminal Sanctions in Addition to Regulatory Penalties, Harvard Law School John M. Olin Center for Law, Economics and Business Discussion Paper Series. Paper 308 1, 5, 17 (2000); James Wilson, Bureaucracy - What Government Agencies Do and Why They Do It (1989).
} 
relationship is that agency problems may occur between them. ${ }^{154}$ Generally, in these relationships the client-principal-cannot fully control the quality of the lawyer'sagent's-performance. ${ }^{155}$ The basis for any principal-agent problem is information asymmetry between the two parties, ${ }^{156}$ which can lead to moral hazard. ${ }^{157}$ The agent uses the principal's inability to assess the value of the steps the agent takes. This does automatically not apply in a context where no lawyer is involved-for example, small claims cases. It plays more strongly whenever mass litigation is an issue.

Essentially, it is crucial to look at the victims' incentives in terms of being potential initiators of claims and the enforcers' incentives with a view to designing a workable system. To finetune the system, the magnitude of the expected sanction and the probabilities of detecting a wrong and convicting the wrongdoer play a role. Ideally, few actual enforcement actions are carried out because of a well-designed system that is a real threat to committing legal violations in the first place. We are, therefore, primarily concerned with the ex ante perspective of potential infringers.

\section{Private or Public Enforcement?}

\section{Rational Apathy, Error Costs, and Information Asymmetry}

We can now analyze how the different factors-rational apathy, error costs, information asymmetries etc. - affect the choice between private and public enforcement. ${ }^{158}$ Essentially, we will examine how different mechanisms affect the incentives of the stakeholders to comply with the law. Different mechanisms may also create different costs. In this respect, we will follow a cost-effectiveness approach, taking a high enforcement level as our goal. Within this approach, the desirable design of law enforcement is identified by comparing

\footnotetext{
${ }^{154}$ See Shavell, The Fundamental Divergence between the Private and the Social Motive to Use the Legal System, 16 J. LEGAL STUD, 575, 599 (1997).

${ }^{155}$ See Steven Shavell, Risk Sharing and Incentives in the Principal and Agent Relationship, 10(1) BELL J. ECON. 55, 57 et seq. (1979); Hugh Collins, Regulating Contracts 236 (1999).

156 See Karl-Gustaf Löfgren, Torsten Persson \& Jorgen W. Weibull, Markets with Asymmetric Information: The Contributions of George Akerlof, Michael Spence and Joseph Stiglitz, 104(2) SCANDINAVIAN J. OF ECON. 195 (2002).

157 See Claudia Keser \& Marc Willinger, Experiments on Moral Hazard and Incentives: Reciprocity and SurplusSharing, in The Economics of Contracts Theories and Applications 293 (Eric Brousseau \& Jean-Michel Glachant eds., 2002), in which a whole Section is devoted to the principal agent problem and moral hazard. Moral hazard arises because an individual does not internalize the full consequences of actions, and therefore, tends to act less carefully than otherwise.

${ }^{158}$ See Franziska Weber \& Michael Faure, The Interplay between Public and Private Enforcement in European Private Law: Law and Economics Perspective, 4 EUR. Rev. PrIV. L. 525 (2015).
} 
the costs and benefits of achieving the stipulated goal. ${ }^{159}$ So, when it is possible to reach the same goal-in our case, the same degree of compliance-through various means, the instrument will be chosen that can reach the particular goal at the lowest cost. The difficulty, however, is that the factors indicated in the previous section often imply a trade-off. This will immediately be clear when addressing the first choice, for example, if enforcement interventions should take place via private or public enforcement. The relevant question in terms of the factors identified in the previous section is whether the additional administrative costs of an enforcement regime add significantly to the probability that eventually a remedy will be imposed. There are a few indicators that may predict whether the one-private-or the other-public-enforcement approach may be more effective. The choice has its origin in the particular sectorial needs.

A first indicator, strongly related to the rational apathy issue identified above, is whether for the particular problem at stake-that hence needs a remedy via enforcement-victims can be identified who can and will act in a private enforcement action. This may clearly be the case when the losses to each individual victim are relatively large-as a result of which, each victim will have sufficient incentives to file a private law suit; those incentives to use the private law system will be substantially lower when it is not possible to identify one particular victim who suffered a loss or when, in other words, the damage is widespread; there are scattered losses. Widespread, scattered losses may therefore be an argument in favor of public enforcement because victims may lack the incentives, given rational apathy, to initiate private enforcement. With-small and-widely dispersed harm, a case can be made for public enforcement, or also some form of group litigation, ${ }^{160}$ to uphold the threat of a lawsuit, as the individual clearly does not have an incentive to sue. ${ }^{161}$ With administrative law enforcement, in the same way as with criminal law enforcement, the public as a financer assumes-large parts of-the risks involved in litigation, leading to lower costs to the individual. ${ }^{162}$ Furthermore, within public enforcement unlike in private enforcement, actions on an own motion are possible. It is common to public authorities that the action they take is beneficial for the whole society. They act in the public interest.

A second indicator may relate to the problem of information asymmetry identified above. In some cases, it may simply be impossible, or in economic terms create excessive

\footnotetext{
159 See Anthony Ogus, Costs and Cautionary Tales: Economic Insights for the Law 283 (2006); George J. Stigler, The Optimum Enforcement of Law, 78 J. OF POL. ECON. 526 (1970).

160 Part of the analysis of public law enforcement may likewise be true for the strengths and weaknesses of group litigation that could not be dealt with in detail in the context of this paper.

${ }^{161}$ See Steven Shavell, The Social Versus the Private Incentive to Bring Suit in a Costly Legal System, 11 J. LEGAL STUD. 333 (1982). To some extent, low cost dispute resolution bodies within the context of private law enforcement, like ADR or mediation, might mitigate the problem.

162 Ultimately, of course, tax payers' money finances the whole system.
} 
administrative costs, for victims to discover the breach or to identify the wrongdoer. When information costs to identify a legal breach for the public at large-or specific victims-are high, there may be substantial advantages in a public enforcement regime. Public enforcement could use economies of scale and expertise of public agencies that would, via an ex ante monitoring regime, be able to discover breaches. In reality, we see how wide investigative powers are available to public authorities, prosecutors, and the police. If law infringements are difficult to discover, an agency's lower costs of information discovery can come in handy; ${ }^{163}$ this is likewise the case when information becomes highly technical; as in the environmental case, for example, when an emission standard has been breached. ${ }^{164}$ Economies of scale generally support using the public law system in this context, particularly if duplication of enforcement costs among private parties were to occur. ${ }^{165}$ When locating wrongdoers, a public authority may have more powers and the ability to cooperate with other authorities-even increasingly with authorities across borders. ${ }^{166}$ Public law enforcement is highly beneficial for tracking down wrongdoers.

Related to this point of information asymmetry is the question of whether legal breaches can be discovered before harm occurs. Private enforcement by victims is necessarily based on harm which has already occurred. Public enforcement may have the advantage that public authorities can engage in ex ante monitoring. This will allow breaches to be discovered even before they have caused harm to victims. ${ }^{167}$ Administrative law enforcement allows for continuous information gathering through monitoring or market studies to detect infringements. Certain existing information asymmetries that private law cannot remedy could to some extent be outweighed by the involvement of a public agency.

Furthermore, in terms of principal agent situations between clients and lawyers, public enforcement scores better because typically the lawyer is less crucial in defending the

\footnotetext{
${ }^{163} \mathrm{~A}$ public enforcer has a lower cost of information discovery because it can use the power of the state-such as the threat of jail, the power of the police to conduct searches and seizures of evidence, clandestine electronic surveillance, and under-cover agents; see llya R. Segal \& Michael D. Whinston, Public Vs. Private Enforcement of Antitrust Law: A Survey, Stanford Law and Economics Olin Working Paper No. 335, 6 (2006). (referring to antitrust cases).

${ }^{164}$ See Shavell, supra note 145 at 270; Hood, Rothstein \& Baldwin, supra note 155, at 73.

165 See Landes and Posner, supra note 147, at 29: An example would be competition authorities that do not only have more resources, but also wide investigate powers that an individual could not make use of. Also economies of scope can speak in favor of the involvement of a public authority; see Michael J. Trebilcock, Rethinking Consumer Protection Policy, in International Perspectives on Consumers' Access to Justice 68, 84 (Charles Rickett \& Thomas Telfer eds., 2003).

166 This is, for example, in the consumer area possible via Regulation 2006/2004 on consumer protection cooperation (referred to as the CPC-Regulation) (O.J. (L 364) of December 9, 2004, p. 1-11).

167 See Fabrizio Cafaggi \& Hans-W. Micklitz, Collective Enforcement of Consumer Law: A Framework for Comparative Assessment, 16(3) EUR. REV. OF PRIV. L. 391, 417 (2008).
} 
victim's point of view. ${ }^{168}$ The actual principal agent situation is given between the public authority and the public at large.

\section{Administrative Costs and Capturing}

For administrative costs, that play a decisive role in the overall cost benefit analysis we tentatively set up the following ranking. Because public enforcement requires ex ante monitoring and engagement of public agencies as well as public enforcement and sanctioning, ${ }^{169}$ administrative costs of public enforcement may be higher than the costs of private enforcement. The consensus is that criminal law enforcement involves very high administrative costs. ${ }^{170}$ In line with our objective to ensure cost-effectiveness, this speaks in favor of using the private law option as long as it leads to an effective result, rather than the public law option unless there is a particular incentive problem that cannot be overcome.

There is a risk of capture of administrative agencies as a result of which they would no longer enforce the law in the public interest to the extent that they are "captured" by the regulated community that they are supposed to monitor. Regulating the susceptibility to capture would lead to additional administrative costs.

\section{Collective Actions and Remedies}

Even if we cannot go into too much detail, we wish to mention that to a large extent collective actions can enhance private law enforcement in a similar way that public law enforcement can. An action becomes more likely because costs-and hence-rational apathy problems are reduced. ${ }^{171}$ Depending on the players involved, additional investigative powers may enter the picture (for example if a public authority is involved). There are some problems particular to mass cases, however, such as the aggravated problem of frivolous

\footnotetext{
${ }^{168} \mathrm{~A}$ problem with public enforcement is, however-as we will discuss below-that public agencies may be subject to capture.

${ }^{169}$ See Donald Wittman, Prior Regulation Versus Post Liability: The Choice between Input and Output Monitoring, 6 J. LEGAL STUD. 193, 207 (1977); overall little empirical research has been done on regulatory agencies within consumer protection; see Stephen Meili, Consumer Protection, in The Oxford Handbook of Empirical Legal Research 176, 186 (Peter Cane \& Herbert Kritzereds eds., 2010).

${ }^{170}$ See Steven Shavell, Foundations of Economic Analysis of Law 49 (2004); Francesco Parisi, The Economic Structure of the Law the Collected Economic Essays of Richard A. Posner 290 (Vol. 1, 2000).

${ }^{171}$ See Hans-Bernd Schäfer, The Bundling of Similar Interests in Litigation. The Incentives for Class Action and Legal Actions taken by Associations, 9(3) EUR. J. L. \& ECON. 183, 186 (2000); Hans-W. Micklitz \& Astrid Stadler, The Development of Collective Legal Actions in Europe, Especially in German Civil Procedure, 17 EUR. BUS. L. REV. 1473, 1476 (2006).
} 
lawsuits ${ }^{172}$ and principal agent situations ${ }^{173}$ and typically higher stakes in the game, which may lead to capture becoming a more severe problem. In a certain sense, introducing group litigation can be seen as an enhancement of private law enforcement.

One can equally think of furthering private law enforcement by introducing low-cost ADR solutions, with its own incentive problems, ${ }^{174}$ or by funding individual claims in different ways-for example, by fine-tuning lawyer remuneration schemes or offering legal insurances-and many others. ${ }^{175}$

Although each of those mechanisms may undoubtedly also have potential risks, they are important because they can improve the functioning of private enforcement and thereby reduce the need to move to the costlier public enforcement system-arguably, however, they make private law costlier to administer so this ratio may at some point also change. Solutions for the lack of deterrent sanctions or rational apathy problems are also imaginable within private law, for instance, by introducing such remedies as punitive damages that increase the stakes in private enforcement. ${ }^{176}$ Either way there are situations in which private enforcement may not provide a remedy. This may occur when ex ante monitoring and ex post investigations by public agencies are necessary to discover legal violations, and when information failures on the side of potential victims mean that particular breaches could never be discovered in a private enforcement mechanism. It may, furthermore, be preferred due to the other reasons given above.

Lastly, a comment on remedies: Individuals cannot generally obtain compensation via public law, which will impact upon the motivation to complain as opposed to private law enforcement. ${ }^{177}$ Note further that the free-riding problem crucially depends on the remedy

172 See Roger Van den Bergh \& Louis Visscher, The Preventive Function of Collective Actions for Damages in Consumer Law, 1 ERASMUS L. ReV. 5, 24 (2008); similarly, see Schäfer, supra note 171, at 184.

${ }^{173}$ See Schäfer, supra note 171, at 199; John C. Coffee Jr, Class Wars: The Dilemma of the Mass Tort Class Action, 95(6) Colum. L. ReV. 1343-1465, 1414 (1995); Susan P. Koniak \& George M. Cohen, Under Cloak of Settlement, 82 VIRGINIA L. REV. 1051, 1113 (1996); Cafaggi \& Micklitz, supra note 167, at 411.

174 This merits a more careful analysis. See Franziska Weber, Is ADR the Superior Mechanism for Consumer Contractual Disputes? - an Assessment of the Incentivizing Effects of the ADR Directive, 38(3) J. CONSUMER POL'Y 265 (2015).

${ }^{175}$ Mark Tuil \& Louis Visschereds, New Trends in Financing Civil Litigation-A Legal, Empirical and Economic Analysis (2010).

${ }^{176}$ There is a strong objection to the introduction of punitive damages in Europe as set out before. Injunctive relief as granted by private bodies may yield similar results in terms of deterrence, see Michael Faure, Anthony Ogus \& Niels Philipsen, Curbing Consumer Financial Losses: The Economics of Regulatory Enforcement, 31(2) LAW \& PoL'Y 161,176 (2009).

177 See Shavell, supra note 144, at 267. Other incentives for an individual are the desire to avoid future harm, the retributive motive, and possibly a fear of reprisal. 
obtained via any enforcement branch and whether profiting from the remedy that others seek is possible. The extent to which the free-riding problem occurs is interrelated with the amount that an individual would need to invest in the law enforcement response-for all.

\section{Summary}

The analysis above shows that, given lower costs of the private enforcement system, it may be preferable to first examine possibilities to improve the functioning of the private enforcement system, in a low cost way, instead of moving to the more costly public enforcement. Public enforcement will therefore necessarily play a secondary role and will only be employed when, for the reasons mentioned above, private enforcement may not prove to be an effective remedy for regulatory breaches. At the same time, the nature of the violation may require a specific enforcement tool, as otherwise incentive problems are capable of impeding law enforcement altogether. So far we have contrasted private law enforcement with public law enforcement. When public enforcement is employed, the next question is whether this should take the form of either administrative or criminal enforcement. The determining factors of this choice have been singled out.

The criteria may thus point in favor of private enforcements if: (1) there are private victims and individual losses are large; (2) victims can easily obtain information on legal violations and regarding the wrongdoer, "information is in private hands"; (3) victims have easy and cheap access to justice-the more important the lower the individual loss; (4) compensation is a desirable goal.

The situations where public enforcement may be preferred are the mirror image: (1) losses are widespread or scattered or no individual victim can be identified; (2) victims may lack information on legal violations or regarding the wrongdoer-low probabilities of detection and conviction in private law; (3) a legal violation may only come to light when substantial harm has occurred.

\section{Administrative or Criminal Enforcement?}

What are the more specific aspects of the two variants of public enforcement? Whereas in both cases the state assumes a large share of the risk, the procedure can work on an own motion and investigative powers are given, there are significant differences between the two procedures, and between the remedies which can be obtained.

There are a number of effects emanating from the less accurate administrative procedural law. This may impact on the speed with which non-meritorious cases are filtered out. Within an administrative procedure the danger of error costs depends on the complexity of the issues to be solved, and on the resources, expertise, and experience of the public 
authority. ${ }^{178}$ The occurrence of error costs is more likely in administrative enforcement compared with criminal law enforcement, because the decision making process is less elaborate. ${ }^{179}$ Therefore, naming and shaming by public authorities is, for instance, regarded as dangerous. ${ }^{180}$ If procedural laws are less accurate, a captured public official is more likely to be able to influence the procedure undesirably.

Criminal procedural law involves an appeal structure, a standard of proof "beyond reasonable doubt" and consideration of the mental element. ${ }^{181}$ Because of the high standard of proof in criminal law, there is a lower probability of convicting the innocent. ${ }^{182}$ Error costs depend on the accuracy of procedural law, and the more accurate the procedure is, the less often errors occur. When errors do occur, the severity of costs to the accused or the victim depends on the severity of the sanctions. Criminal law enforcement typically includes more severe sanctions than administrative law enforcement. ${ }^{183}$ Stigma, for example, inflicting a strong disapproval of particular behavior by society, if it is involved in a sanctioning mechanism, leads to higher error costs. The reason is that stigma, once inflicted, is difficult to restore. High sanctions available in criminal law enforcement are also interesting for deterrence purposes to induce compliance in particular when probabilities of detection and conviction are low. ${ }^{184}$ Error costs need to be reduced because where they would be widely spread, the result would affect many individuals.

Criminal law enforcement's investigative powers are even wider than the classical investigative powers that an administrative authority has. In particular, where other enforcement systems would be impeded, criminal law enforcement-the police-is able to locate and apprehend certain wrongdoers and initiate a procedure. Criminal law typically

\footnotetext{
${ }^{178}$ See Van den Bergh, supra note 31, at 195; See also Anthony Ogus, Enforcing Regulation: Do we need the criminal law?, in New Perspectives on Economic Crime 42, 44 (Hans Sjörgen \& Göran Skogheds, 2004) (distinguishing the burden of proof and procedural safeguards between criminal law and administrative law from high to low).

${ }^{179}$ See Garoupa \& Gomez-Pomar, supra note 153, at 5; Faure, Ogus \& Philipsen, supra note 176, at 176.

${ }^{180}$ For details see Faure, Ogus \& Philipsen, supra note 176 , at 176.

181 See Roger Bowles, Michael Faure \& Nuno Garoupa, The Scope of Criminal Law and Criminal Sanctions: An Economic View and Policy Implications, 35(3) J. L. \& Soc'Y 405 (2008); Roberto Galbiati \& Nuno M. Garoupa, Keeping Stigma out of Administrative Law: An Explanation of Consistent Beliefs, 15 SUP. CT. ECON. REV. 274 (2007); Keith Hylton \& Vikramaditya Khanna, Toward an Economic Theory of Pro-Defendant Criminal Procedure, Discussion paper No. 318.3 (2001).

182 See Richard A. Posner, An Economic Approach to Legal Procedure and Judicial Administration, 2(2) J. LEGAL STUD. 399, 410 (1973).

183 See Van den Bergh, supra note 31, at 196.

${ }^{184}$ See Polinsky \& Shavell, supra note 15051, at 419. On low probabilities of detection; see also Landes \& Posner, supra note 148 , at 36 . There is also the possibility to impose fines that exceed the harm.
} 
deals with the cases for which the likelihood of apprehending and convicting offenders is assumed to be low. ${ }^{185}$

One important difference between the two is that criminal law can be effective against a particular type of wrongdoer, namely the one that turns out to be "judgment-proof". An important advantage of criminal law enforcement in this respect is that the system's various available sanctions include non-monetary ones, primarily imprisonment, which serve to remedy the issue of a judgment-proof defendant. ${ }^{186}$ Imprisonment is essential as a deterrent ${ }^{187}$ and is the optimal sanction when the probability of detection and conviction is low and the likelihood of defendants being insolvent is high. ${ }^{188}$ Sanctions such as license revocation available to a public agency might, however, be effective with regard to a judgment-proof wrongdoer. ${ }^{189}$ When administrative law can take ex ante action, criminal law is interesting because, unlike other enforcement responses, attempts to do harm can also be sanctioned. ${ }^{190}$

When we argue that criminal law is superior to administrative law because of a reduced risk of capture, we need to consider that this may not be true for the public prosecutor, who plays an important role and is able to exercise a considerable amount of discretion. ${ }^{191}$

As mentioned, criminal law is the costlier mechanism to administer. Therefore, administrative law should be used as long as it still provides desirable results. In summary, criminal law enforcement becomes necessary where: (1) the risk of capture of administrative agencies is a severe impediment; (2) where the additional investigative powers are needed/ where probabilities of detection are very low; (3) if wrongdoers are judgment proof; (4) in

\footnotetext{
185 See Shavell, supra note 1444 , at 275.

186 See Bowles, Faure \& Garoupa, supra note 181, at 402; Steven Shavell, Criminal Law and the Optimal use of Nonmonetary Sanctions as a Deterrent, COLUM. L. REV. 1247 (1985); Shavell, supra note 165, at 544.

187 See Polinsky \& Shavell, supra note 15050, at 435. If a person is old or dying from a disease, however, imprisonment cannot fulfil its full purpose; see Shavell supra note 166, at 532. Here, for example, incapacitation measures are necessary and desirable.

188 See Bowles, Faure \& Garoupa, supra note181, at 405.

189 See Trebilcock, supra note 16565 , at 84; See Faure, Ogus \& Philipsen, supra note 17676 , at 178 , expand on the issue of licenses and how this can possibly have a higher deterrent effect for traders than imprisonment.

${ }^{190}$ See Shavell, supra note 165 , at 571.

191 In most legal systems, prosecutors are part of the independent judiciary and stand under the control of the Minister of Justice who is subject to political control. He is supposed to make decisions on prosecution and hence use his discretion in the public interest. Systems of transparency and accountability, however, can help to guarantee that this will effectively be the case in practice. If those are lacking, there is a danger that the available discretion would be abused.
} 
complex-mass-cases where we need to see a reduction of error costs; (5) when it becomes relevant to impose stigmatizing sanctions.

Consequently, where the risks of the less accurate procedural law, linked with effects of capture, effect on error costs and frivolous lawsuits are less problematic, administrative law should be used. Further considerations are the additional investigative powers and the set of judgment-proof offenders.

Notably, whereas civil procedural law and the public law option of administrative law can be contrasted regarding the possibility of obtaining compensation, criminal law is a special public law enforcement tool. In some jurisdictions compensation can be granted via the criminal law branch. ${ }^{192}$

\section{The Enforcement Matrix}

In this section, we wish to summarize by way of designing a matrix to illustrate the circumstances in which generally private enforcement, or more specifically, civil sanctions and private liability, could be an effective remedy for violations. The starting point is to look for the mechanism that can reach the goal of legal compliance, which is defined by European law, at the lowest cost. Given the analysis above, tentatively this means that from the point of view of administrative costs the first best solution is private enforcement, second best is administrative enforcement and third best is criminal enforcement. Situation-specific incentive problems may, however, change this ranking. Moreover, when it is possible to improve incentive problems of private enforcement at relatively low costs within the private law enforcement framework, this would be preferred because it can reduce the need to move to more costly systems of public enforcement. ${ }^{193}$ This is true up to the point where these costs would be higher than adding or alternatively reverting to public law enforcement. In some cases, the remedies to improve the functioning of private enforcement, such as, for example, introducing group litigation may create its specific problems-and costs-as well. Hence, in practice the desirability of improving private enforcement will also have to be traded off against the need to use public enforcement. In sum the following matrix can be designed:

\footnotetext{
192 The European country in which this is most developed seems to be Norway: John T. Johnsen, Enforcement of Civil Claims in Criminal Litigation: The Norwegian Example, in Enforcement and Enforceability-Tradition and Reform 313-326 (Remco van Rhee \& Alan Uzelaceds, 2010); for Germany see §§ 403-406d Strafprozessordnung (Act on Criminal Procedure, StPO). Similar provisions exist also in Belgium, France, and the Netherlands, see Anthony Ogus, Michael Faure, and Niels Philipsen, Best Practices for Consumer Policy: Report on the Effectiveness of Enforcement Regimes, in Report prepared for the UK Department of Trade and Industry and OECD 37 (2006).

${ }^{193}$ We do realize that this entails the heavy assumption that improving private enforcement is usually less costly than using public enforcement.
} 


\begin{tabular}{|c|c|c|c|}
\hline \multicolumn{2}{|c|}{ Private enforcement } & \multicolumn{2}{|c|}{ Public enforcement } \\
\hline $\begin{array}{l}\text { Recommended if: } \\
\text { - Individual large } \\
\text { losses } \\
\text { - Violation clear } \\
\text { - Probability of } \\
\text { detection } \\
\text { 100\%/high } \\
\text { - Good access to } \\
\text { justice } \\
\text { - Compensation } \\
\text { matters }\end{array}$ & $\begin{array}{l}\text { Contra-indications: } \\
\text { - Small (widespread) } \\
\text { losses } \\
\text { - Bad info on breach } \\
\text { or wrongdoer } \\
\text { - Expertise/ } \\
\text { Investigations and ex } \\
\text { ante monitoring } \\
\text { needed } \\
\text { - If probability of } \\
\text { detection < } 100 \% \\
\text { - If access to justice } \\
\text { low (because rational } \\
\text { apathy is at play etc.) }\end{array}$ & $\begin{array}{l}\text { - } \\
\text { - Reduces costs for } \\
\text { individuals } \\
\text { - Ex ante } \\
\text { monitoring/ } \\
\text { Intervention before } \\
\text { breach causes } \\
\text { harm \& } \\
\text { Investigative } \\
\text { powers to detect } \\
\text { breach } \\
\text { - Can impose high } \\
\text { sanctions } \\
\text { - Solves judgment- } \\
\text { proof issue }\end{array}$ & $\begin{array}{l}\text { - } \\
\text { - Administrative } \\
\text { costs higher } \\
\text { - Capture risk } \\
\text { (particularly if } \\
\text { administrative) } \\
\text { - Error costs } \\
\text { (particularly if } \\
\text { administrative) }\end{array}$ \\
\hline $\begin{array}{l}\text { Cures for } \\
\text { - Group litigation } \\
\text { - ADR procedures/ } \\
\text { value claims } \\
\text { - Any type of fund } \\
\text { - Punitive damage }\end{array}$ & $\begin{array}{l}\text { tra-indications: } \\
\text { nediation capture low- } \\
\text { g of claims } \\
\text { rcement unavoidable } \\
\text { ); cases (requiring be by way of } \\
\text { the help of a public }\end{array}$ & $\begin{array}{l}\text { Administrative } \\
\text { enforcement } \\
\text { recommended if: } \\
\text { - Benefit to } \\
\text { violator not high } \\
\text { - P of detection } \\
\text { reasonable } \\
\text { - Case not too } \\
\text { complex } \\
\text { - No need for non- } \\
\text { monetary sanctions } \\
\text { - Not too many } \\
\text { individuals } \\
\text { affected; otherwise } \\
\text { mistake may } \\
\text { spread } \\
\text { - No need to } \\
\text { impose stigmatizing } \\
\text { sanction }\end{array}$ & $\begin{array}{l}\text { Criminal } \\
\text { Enforcement very } \\
\text { costly, hence only } \\
\text { recommended if: } \\
\text { - Benefit of } \\
\text { violation high } \\
\text { - P of detection low } \\
\text { - Need for non- } \\
\text { monetary sanctions } \\
\text { - Need to impose } \\
\text { stigmatizing } \\
\text { sanctions } \\
\text { - Avoiding capture } \\
\text { is crucial }\end{array}$ \\
\hline
\end{tabular}

Table 2: The enforcement matrix 


\section{E. Narrowing Down the I \& E Findings to the Individual Areas}

In this section, the general findings from the law and economics literature will be applied to the four selected areas. We will ask the simple question-but the answer is obviously not simple at all-whether the nature of the particular areas and the potential violations involved give rise to a particular mix of private, administrative, or criminal enforcement with a view to their comparative advantages.

\section{Consumer Law}

There is undoubtedly room for individual private enforcement of consumer law, to the extent that individual consumer losses are large. The classic example that is often provided is the one of a disappointing holiday. ${ }^{194}$ This is an obvious case where the losses could be large inducing an individual consumer to act. There may, however, be many cases as well where losses are small (and possibly widespread) and hence a rational apathy problem could occur. Examples include unsound investment advice by a financial consultant, nontransparent price calculations, ${ }^{195}$ and the signing without reading of standard form contracts. ${ }^{196}$ Moreover, there are also possibilities to improve the rational apathy problem as well as to increase access to justice by ADR solutions, for instance. All solutions mentioned in the matrix could be of use.

More particularly, with some of the examples of widespread, scattered losses ex ante monitoring via a public enforcement agency may be indicated. Also in consumer law, some public enforcement may be required. The advantage of public enforcement in the consumer law case is that with ex ante monitoring by an agency it becomes possible to discover and remedy breaches that individual consumers may not discover. Likewise, detailed investigations may be beneficial and necessary for certain types of violations and wrongdoers. In most cases, administrative sanctions and more particularly administrative fines may suffice. ${ }^{197}$ The benefits to the violator will not often be that high, detection of violation by public authorities is still possible and there may be no need to impose a stigmatizing sanction. In case of so-called rogue traders, however, who intentionally violate consumer law to obtain profits, there may be a need to refer to criminal sanctions and even

\footnotetext{
${ }^{194}$ Van den Bergh, supra note 31, at 195.

${ }^{195}$ Van den Bergh, supra note 31, at 186.

196 Gerrit De Geest, The Signing-without-reading Problem: An Analysis of the Directive on Unfair Contract Terms, in KonsequenzenwirtschaftlicherNormen 213 (Hans-Bernd Schäfer\& Hans-Jürgen Lwowskieds, 2002).

197 See Faure, Ogus \& Philipsen, supra note 176, at 173-76.
} 
imprisonment in extreme cases. ${ }^{198}$ This could more particularly be the case when the traders' conduct is generating large amounts of damage to the public ${ }^{199}$ and when the trader would be a "fly by night" operator who regularly leaves insolvent companies behind and would thus not be deterred through administrative sanctions.

In sum: (1) private enforcement may be the primary instrument; (2) all "internal" solutions to improve the working of private enforcement could be employed here; (3) for particular cases of small and widespread losses and those which are difficult to detect and where the wrongdoer is difficult to locate, public enforcement may be indicated; (4) in most cases, administrative sanctions will suffice; an administrative agency is limited regarding the remedies, therefore this route is only desirable where injunctions or fines, typically available to such authorities, are sought. This may be particularly interesting if the agency acted on an own motion; (5) there is only a need to resort to the criminal law in extreme cases-rogue traders. It can function as a backup. If it does, the possibility of obtaining damages via criminal law may be interesting. Criminal sanctions should always be available for cases of judgment-proof wrongdoers.

\section{Competition Law}

Again, there is substantial scope, as in the consumer law case, for applying private enforcement. The case for private enforcement in the competition law case may even be stronger because the victims in this case may not only be consumers, but potentially other traders-suffering from the anti-competitive behavior-as well or professional buyers in the supply chain. ${ }^{200}$ To provide them with incentives to sue from an economic point of view, punitive damages may be warranted. ${ }^{201}$ To solve the rational disinterest of named individuals, group litigation, and funding solutions may be of help. Alternatively, administrative fines may do.

\footnotetext{
198 This was discussed in the same way at the Fachexpertengespräche 2014 with consumer law experts from Germany, Austria, Switzerland, Luxemburg and Liechtenstein at the Federal Ministry of Justice and Consumer Protection, Berlin, 16/17 November 2014.

${ }^{199}$ Faure, Ogus \& Philipsen, supra note 176, at 180.

200 A strong case in favor of private law enforcement is made by Joshua P. Davis \& Robert H. Lande, Defying Conventional Wisdom: The Case for Private Antitrust Enforcement, 48 GA. L. REV. 1 (2013). The same authors acknowledge a stronger deterrent effect of private law enforcement than of criminal law enforcement of antitrust laws in the US. Robert H. Lande \& Joshua P. Davis, Comparative Deterrence From Private Enforcement and Criminal Enforcement of the U.S. Antitrust Laws, BYU L. REV. 315, 317 (2011). Given the different nature of law enforcement in the US and the EU, they assert a positive effect of the Directive on antitrust damages and claim that it does not go far enough (Robert H. Lande, The Proposed Damages Directive: The Real Lessons from the United States, (2014), University of Baltimore Legal Studies Research Paper No. 2014-19.

${ }^{201}$ See for a detailed analysis of the advantages and disadvantages of punitive damages, Lotte Meurkens, Punitive Damages: The Civil Remedy in American Law, Lessons and Caveats for Continental Europe (2014).
} 
The costs of uncovering violations of competition law may sometimes be quite high. ${ }^{202}$ Traders may easily conceal breaches of competition law and especially for consumers at large the necessary expertise to identify anti-competitive behavior may be lacking. The need for public enforcement in the competition law case may, therefore, be even stronger-given the highly technical nature of the violation-than in the case of consumer law.

Again, in most cases administrative fines may suffice to deter violations of competition law. There may be cases, however-for example, price fixing via hard core cartels-where breaches are clearly intentional and where traders will take special care to hide their anticompetitive behavior, thus reducing the probability of detection. Moreover, potential benefits of violations may be substantially higher than in the case of consumer law. ${ }^{203}$ This may therefore bring about a need to impose high monetary sanctions to outweigh the low probability of detection and high potential profits. In some cases, those optimal monetary sanctions may be higher than the assets of the trader involved in the anti-competitive behavior. So that may justify the need for the use of criminal sanctions-more particularly imprisonment-for exceptional cases of anti-competitive behavior. ${ }^{204}$

Summarizing: (1) private enforcement can again be the primary tool; (2) solutions to improve private enforcement, more particularly group litigation and punitive damages, can be employed; (3) given that it is difficult to detect the nature of the violations public enforcement is certainly needed; (4) in most cases administrative enforcement-via finesmay suffice; (5) but given the high potential profits and low probability of detection, criminal sanctions-non-monetary sanctions-may be needed as well.

\section{Environmental Law}

Again, environmental damage may cause harm to individual victims, thus justifying private enforcement, but in many cases environmental harm may be widespread and could damage a large area and many victims; there may be some cases that cause no direct harm to individuals at all. There may, however, also in the environmental area, be scope to improve private enforcement. One way of dealing with rational disinterest is to grant the right to sue

\footnotetext{
202 Van den Bergh, supra note 71, at 17.

203 Generally, violations of competition law-more particularly, hardcore cartels-can generate high gains, in principle substantially higher than, for example, misleading advertising on a-still-competitive market.

204 See Wouter P.J. Wils, Is Criminalization of EU Competition Law the Answer?, 28 WORLD COMPETITION 117 (2005); Roger Van den Bergh \& Michael Faure, Critical Issues in the Enforcement of the Anti-Monopoly Law in China: A Law and Economics Perspective, in Competition Policy and Regulation. Recent Developments in China, the US and Europe 54, 56 et seq. (Michael Faure \& Xinzhu Zhang eds., 2011).
} 
on behalf of the environment to NGOs-in order to remedy the breach of environmental law, ADR solutions may also improve access to justice. ${ }^{205}$

The problem is that breaches of environmental law may lead to substantial damage when they occur and, moreover, those breaches will often not be discovered on the basis of complaints. Often violations of environmental law are of a highly technical nature, which requires specific expertise. This is a clear case where ex ante monitoring via public enforcement is necessary to detect breaches. Priority will therefore be with the public enforcement system and more particularly with environmental breaches that cannot be easily discovered; the role for private enforcement is mostly given where private nuisance causes harm to individual victims.

Many breaches of environmental regulations can be deterred via administrative fines. ${ }^{206}$ This is especially the case for so-called administrative violations, for example, where administrative rules are violated but no concrete environmental harm has been causedyet. The benefits of those administrative violations may be limited and public authorities may easily discover the violation as a result of which the probability of detection should not be low. In those cases administrative fines may also suffice because there is no need to impose stigmatizing sanctions. In some cases, however, the benefit to the perpetrator and the social cost to society may be substantially larger. That may be the case when the violation does not only consist of a breach of regulatory duties, but also of concrete harm to the environment, e.g. through emissions or disposal of waste. Those violations are often intentional, lead to huge benefits, e.g. avoiding the payment of fees for legal waste disposal, and the probability of detection, for example, to discover who illegally deposited dangerous waste, may be low. These could well be cases where criminal enforcement may be indicated, and also where benefit from the stigmatizing effect of the criminal sanction may be gained. ${ }^{207}$

Summarizing: (1) the primary enforcement system for most environmental violations may be public enforcement; (2) private enforcement may still play a subsidiary role where environmental harm reaches individual victims; (3) rights of actions of NGOs and ADR may remedy rational disinterest and barriers to access to justice; (4) administrative fines may suffice in cases of violation of regulatory-administrative-duties; (5) when concrete harm to the environment is caused, criminal enforcement has its place.

\footnotetext{
${ }^{205}$ See Michael Faure \& Franziska Weber, Dispersed Losses in Tort Law-An Economic Analysis, 6(2) J. EUR. TORT L. 163 (2015).

206 This has inter alia strongly been argued by Anthony Ogus \& Carolyn Abbot, Sanctions for Pollution: Do We Have the Right Regime?, 13 J. ENVTL. L. 283 (2002).

${ }^{207}$ Michael Faure, Environmental Crimes, in Criminal Law and Economics 320 (Vol. 3, Nuno Garoupa ed., 2009).
} 


\title{
IV. Insider Trading Law
}

The insider trading case is to some extent comparable to the competition law case in the sense that different victim groups could be distinguished that may have different incentives to use private enforcement. On the one hand, there is the potentially large group of individuals active on the stock market who may feel disadvantaged as a result of the insider trading because, if they had had the inside information, they could have made profits as well. This group is potentially very large and the losses may be widespread as a result, of which the rational disinterest will be large. ${ }^{208}$ On the other hand, there may also be a group of shareholders of the particular company in which insider trading of shares took place, who are much more directly affected by the consequences of the inside trade. This will, more particularly, be the case when insiders were aware of bad news, sold stock, and, in this way, also created a further decline of stock prices to the-alleged-detriment of other shareholders who lacked the inside information. For them the incentives to use the private enforcement system may be substantially larger, given their more direct involvement in the company and presumably larger losses suffered. Moreover, to the extent that rational disinterest or access to justice problems would exist, the solutions mentioned; more particularly group litigation, punitive damages and fine-tuning lawyer remuneration, could provide a remedy. Again, there are traditional reasons to argue that private enforcement may not suffice. ${ }^{209}$ The problem with insider trading remains that it can be extremely difficult to discover insider trading, more particularly given the fact that this is based on "inside" information and that the trading may often take place indirectly via so-called tippees. ${ }^{210}$ This may require monitoring by public enforcement agencies and hence public enforcement. There may be an information problem with private enforcement because the necessary evidence cannot be collected. ${ }^{211}$ For this and other reasons-for example, a lot of

${ }^{208}$ See Michael Faure \& Claire Leger, Towards a Harmonization of Insider Trading. Criminal Law at EU Level?, 9(2) BRooklyn J. CORP., Fin. \& COMmerCIAL L. 387 (2015); Nasser Arshadi, Insider Trading Liability and Enforcement Strategy, 27(2) FIN. MGMT. 70, 71 (1998) (regarding the US law at that time):

\begin{abstract}
Since managers and directors are often the beneficiaries in insider trading, they have little incentive to sue; given that most shareholders own a small fraction of the outstanding shares, they often cannot afford the cost of taking legal action. The principal incentive to the enforcement of this section is left with attorneys who track 16(a) filings and file suit on behalf of a small shareholder where the court grants fees for the plaintiff's attorneys.
\end{abstract}

\footnotetext{
${ }^{209}$ Standard literature: Polinsky \& Shavell, supra note 151-public enforcement is optimal when it is too costly for the individual to identify the wrongdoer.

${ }^{210}$ This refers to persons providing "tips", meaning, relevant information which may affect stock prices. James D. Cox, Insider Trading and Contracting: A critical response to the "Chicago School", DUKE L. J. 628, 658 (1986) sees scope for economies of scale and benefits of public enforcement.

${ }^{211}$ This is suggested for the US context, Ventoruzzo, supra note 1140, at 589.
} 
circumstantial evidence-private individuals are allegedly rarely motivated to sue. If wellcoordinated, one may see a scope for private law enforcement being aided by information generated within public law enforcement. ${ }^{212}$

In many cases of insider trading, administrative enforcement and more particularly administrative fines may suffice. One reason is that the benefit generated through insider trading may not be that large. A study in the US showed that the median gain or loss in insider trading cases was $\$ 25,800 .{ }^{213}$ A problem with insider trading though, is that the probability of detection may not be large. Given the fact that it concerns violations dealing with confidential and anonymous information where often proxies or intermediaries are used, it may be difficult to detect insider trading. ${ }^{214}$ Given these indications, insider trading may need substantial administrative fines to outweigh the lower probability of detection. Insider traders, however, can be assumed to belong to the community of rather wealthy individuals who may not directly be judgment proof. As a result, in most cases insider trading may be deterred through administrative fines without the need to resort to criminalization.

Drawing some more inspiration from the US context, it is voiced how insider trading is "an extraordinarily difficult crime to prove." ${ }^{\prime 15}$ Direct evidence of insider trading is rare, evidence is almost entirely circumstantial and difficult to assemble in the right way. Therefore, public enforcement may be more warranted. Private enforcement plays a minor role, though. ${ }^{216}$ A recent study suggests that one may need to distinguish cases: Individual actors are unlikely to discern insider trading in impersonal markets. ${ }^{217}$ Here, public enforcement may be warranted.

In a related field, securities law, effective strategies may be an emphasis on standardized disclosure and a reliance on private dispute resolution, using tools that facilitate recovery of

\footnotetext{
212 Private actions in the US are arguably free-riding on the investigations carried out by the SEC, see Cox, supra note 210 , at 658 .

${ }^{213}$ Elizabeth Szockyj \& Gilbert Geis, Insider Trading: Patterns and Analysis, 30 J. CRIM. JUST. 273 (2002).

${ }^{214}$ See Jonathan R. Macey, Insider Trading: Economics, Politics and Policy 5 (1991); Frank H. Easterbrook, Insider

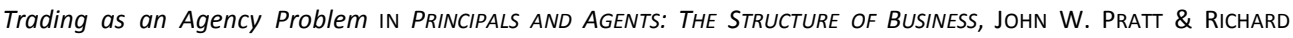
ZECKHAUSER EDS, 81 (1985).

215 Thomas C. Newkirk, Speech by SEC Staff: Insider Trading-A U.S. Perspective, https://www.sec.gov/news/speech/speecharchive/1998/spch221.htm (last visited Mar. 3, 2016).

${ }^{216}$ See J.C. Coffee Jr., Introduction: Mapping the Future of Insider Trading Law: Of Boundaries, Gaps, and Strategies, Colum. BuS. L. REV. 281 (2013), footnote 3, observing that "insider trading is seldom enforced through private litigation, but instead through criminal and SEC enforcement." as quoted by Ventuzzo.

217 Laura N. Beny, Do Insider Trading Laws Matter? Some Preliminary Comparative Evidence, 7(1) AM. L. \& ECon. ReV. 144, 176 (2005).
} 
losses by investors. ${ }^{218}$ These were shown to influence growth in the stock market. They found no clear evidence that a public regulator or criminal sanctions would matter.

Summarizing: (1) private enforcement may be an interesting tool to deter some insider trading; (2) solutions to deal with the rational disinterest, such as group litigation, punitive damages or special fee agreements with lawyers, may improve the working of private enforcement; (3) given the difficulty of detecting insider trading, public enforcement and ex ante monitoring may be indicated; (4) in most cases, administrative fines may suffice to deter insider traders; (5) there does not seem to be an immediate need to resort to criminal sanctions, unless one wanted to profit from stigmatizing the offender.

\section{Assessing the EU's Approach in the Light of the Economic Analysis of Law}

\section{The EU Versus the Matrix}

In the same way we summarized the EU approach to enforcement in the four domains, ${ }^{219}$ we can now summarize which would be the optimal use of the various enforcement mechanisms from the perspective of the optimal model. The findings just presented can be summarized as follows:

\begin{tabular}{|l|l|l|l|}
\hline & Private & Administrative & Criminal \\
\hline Consumer & Yes & Yes & $\begin{array}{l}\text { Limited (for rogue } \\
\text { traders) }\end{array}$ \\
\hline Competition & Yes & Yes & Yes \\
\hline Environment & Limited & Yes & Limited \\
\hline IT & Limited & Yes & Very Limited \\
\hline
\end{tabular}

Table 3: The enforcement matrix applied

The mismatch of the European approach to law enforcement and an economic approach becomes immediately apparent when we confront the optimal solutions with EU law. We can relatively simply compare the EU approach towards enforcement, as it was summarized

\footnotetext{
${ }^{218}$ As identified by Rafael La Porta, Florencio Lopez-De-Silanes \& Andrei Shleifer, What Works with Securities Law, LXI(1) THE J. FIN. 1, 27 (2006). Beny, supra note 2173, at 174 finds, on the other hand, that public law enforcement seems to be more important. The most deterrent effect stems from the possibility to impose criminal sanctions. The author acknowledges, however, that no account was taken of liability rules, allocations of evidentiary burdens or general rules of litigation, and administrative procedure (p. 176) which is why no strong conclusions can be drawn from the study yet.

${ }^{219}$ See supra Table 1.
} 
in table 1 with the ideal model based on the literature, as it was summarized in table 3 . A merged table looks like this:

\begin{tabular}{|l|l|l|l|l|l|l|}
\hline & \multicolumn{2}{|l|}{ Private } & Adm. & \multicolumn{2}{l|}{ Crim. } \\
\cline { 2 - 7 } & Model & EU & Model & EU & Model & EU \\
\hline Cons. & Yes & $\begin{array}{l}\text { Yes } \\
\text { Injunctions } \\
\text { ADR/mediation }\end{array}$ & Yes & $\begin{array}{l}\text { Limited/only } \\
\text { CPC context }\end{array}$ & $\begin{array}{l}\text { Limited } \\
\text { (for } \\
\text { rogue } \\
\text { traders) }\end{array}$ & No \\
\hline Comp. & Yes & $\begin{array}{l}\text { Yes } \\
\text { Directive }\end{array}$ & Yes & $\begin{array}{l}\text { Yes } \\
\text { Provisions on } \\
\text { fines }\end{array}$ & Yes & No \\
\hline $\begin{array}{l}\text { Env. } \\
\text { Insider } \\
\text { Trading }\end{array}$ & Limited & $\begin{array}{l}\text { Limited (only } \\
\text { ELD) }\end{array}$ & Yes & No & Limited & Yes \\
\hline
\end{tabular}

Table 4: The EU and enforcement matrix combined

This interesting table, comparing the different approaches towards enforcement in the EU with the ideal enforcement model, shows that for some particular domains the EU approach seems to follow the model, whereas for others it does so less. Moreover, it provides some explanation for the differences that could be found in the EU approach towards enforcement as summarized in table 1 , but only to some extent.

Taking the private law approach, this is present, as the model suggests, in the consumer law area and is further suggested-again in line with the model-in the domain of competition law. It is, however, completely absent in the EU approach towards insider trading, whereas according to the model there may be room for private enforcement of insider trading as well. The EU legislation regarding private law enforcement of environmental law is largely in line with the suggestions.

Administrative enforcement-public enforcement, thus providing powers for pro-active monitoring, but also administrative fines for minor offences-is in fact needed for all cases, based on the theoretical approach. In the EU, it is only the primary instrument in competition law, and it has been-modestly-suggested in the consumer law area-the authorities have no competences to fine traders - and was the predominant system in the domain of insider trading before the 2014 Directive introduced criminal sanctions. In the environmental area it is, at least at EU level, completely absent. 
The strongest differences between the model and the EU approach seem to appear in criminal law. There is a strong theoretical argument in favor of criminalizing competition law, for all three other policy areas the reasoning is less strong-for example, only for few incidents of rogue traders or for particular cases of concrete endangerment of the environment. For insider trading, the argument for criminalization is rather weak. Here, surprisingly, the EU comes to opposite results, having forced MS to criminalize strongly in the environmental area, which to some extent can still be understood, but also in the field of insider trading-where it may be less obvious. Criminalization is, however, totally absent in the domains of competition law, where it is strongly indicated, and consumer law where, at least for particular cases, it may be indicated. This shows clear inconsistencies when in comparable contexts, criminal law is suggested or not.

Also, when one looks at the differences in approaches in a horizontal way, which addresses the different sectors, the deviations are obvious. The areas of consumer and environmental law are most aligned with the suggestions from the model, but that is surely not the case for insider trading where there is a strong reliance on criminalization and possibilities of private enforcement are not explored at all.

Of course, to some extent one could argue that it would not suffice to merely look at enforcement instruments at EU level because in most of the domains that have been discussed, MS have also developed enforcement rules. That is undoubtedly the case, but it does, if only to a minor extent explain the striking differences in approaches between the different areas. It would only make sense if, for example, the EU would have established that private enforcement has been developed in a satisfactory manner for insider trading at MS level and that for that reason-given subsidiarity-no EU action in that domain is warranted. Similarly, the EU could have examined whether criminalization of competition law already sufficiently exists at Member State level, which would reduce the need for such a measure at EU level. But such exercises have not been undertaken and so could not serve as a justification for the differences. Moreover, the deviations from the model at EU level do not always represent a flaw; in the sense that the EU does not suggest enforcement whereas the model would. In particular cases, such as criminal law, the EU approach may go too far, compared to the model. Especially when comparing the combination of different instruments, it is striking that in particular domains-such as the environment-the focus has been solely on one instrument-criminal law-whereas the possibilities to develop other instruments-private and administrative enforcement-have not been sufficiently examined. For insider trading the focus has lately shifted from administrative to criminal law, leaving the addressees doubting the precise interaction. Hence, in those domains EU law also misses out in the "smart mixes" of policy instruments. ${ }^{220}$ Clearly the approach within the EU as such lacks coherence and cannot be explained by an economic rationale.

220 See generally on policy mixes, the seminal work of Neil Gunningham \& Peter Grabosky, Smart Regulation. Designing Environmental Policy (1998). 


\section{Explaining Divergences: An Attempt}

Generally, various explanations are provided in the literature when at a regulatory level particular deviations are found from the optimal design. One such powerful explanation is the influence of strong interest groups. Public choice theory has predicted that particularly single-issue oriented interest groups may lobby the government in order to extract rents from beneficial regulation. ${ }^{221}$ Others have argued that bureaucrats could be "captured" by the regulated industry. ${ }^{222}$ The danger of regulation being made to favor private rather than public interests is supposed to be especially large when there is no counter-vailing power to balance the influence of industry. ${ }^{223}$ It has especially been held that in an environment where there is little transparency and hence high information costs for the public at large, the likelihood that special interest groups will succeed in obtaining legislation to their advantage may increase. Some have argued that the EU is an ideal forum for successful lobbying by interest groups, given the complex and rather opaque decision-making at the EU level. ${ }^{224}$ Hence, some of the deviations we found could be explained by interest group politics. That would then especially be a factor explaining why particular efficient instruments have not been introduced at EU level. For example, for the area of competition law, one could well imagine that industry would lobby against criminalization. It is then difficult to understand, however, why industry would be successful in opposing criminalization in the field of competition law, but not in the areas of environment and insider trading where they are presumably equally strong. Further detailed research, explaining the relative strength of the particular interest groups in that field, might provide further insights, but at first look the interest group explanation does not seem to be particularly powerful. Obviously, interest groups could also, instead of directly lobbying the EU level, lobby national politicians which could lead to MS exercising pressure on the EU level in favor of or against a particular enforcement strategy. Even if it were MS, however, rather than interest groups directly that would lobby at EU level, it is still not understandable

${ }^{221}$ See generally Jane S. Shaw, Public Choice Theory (2002), http://www.econlib.org/library/Enc1/PublicChoiceTheory.html (last visited March 3, 2016) (discussing public choice theory, which models the way that interest groups affect collective decision making); see Michael T. Maloney \& Robert E. McCormick, A Positive Theory of Environmental Quality Regulation, 25 J. L. \& Econ. 99 (1982).

222 See generally George J. Stigler, The Theory of Economic Regulation, 2(1) BeLL J. OF ECON. 3 (1971); Sam Peltzman, Toward a More General Theory of Regulation, J. L. \& ECON. 211 (1976).

223 See generally Gary S. Becker, A Theory of Competition among Pressure Groups for Political Influence, 98(3) QUARTERLY J. ECON. 371, 386, 394-95 (1983), (asserting that non-cooperative competition between pressure groups for political influence favors efficiency). Empirical evidence of the importance of such a countervailing power is, in the environmental area, inter alia provided by Seth Binder \& Eric Neumayer, Environmental Pressure Group Strength and Air Pollution: An Empirical Analysis, 55(4) ECOLOGICAL ECON. 527, 528 (2005).

${ }^{224}$ See Michael Faure, Jürgen Lefevere \& Roger Van den Bergh, The Subsidiarity Principle in European Environmental Law: An Economic Analysis, in Law and Economics of the Environment 121 (Erling Eide \& Roger Van den Bergh eds., 1996). 
why, for example, MS would lobby in favor of criminal enforcement in the cases of environmental and insider trading law and not in other domains.

A second line of reasoning consists of what is referred to as "path dependency". This refers to the fact that institutions and individuals often continue on a chosen path, simply because this is how it happened in the past, not questioning whether that is the best solution. ${ }^{225}$ Path dependency could, for example, explain that in the environmental area, because the case law of the court of justice of the EU awarding the Commission competences to force MS towards criminalization, ${ }^{226}$ the entire focus of the Commission has merely been on criminalization, thus not paying attention to the question of whether the same goals could equally be reached with other instruments-private enforcement or administrative enforcement. Bureaucrats would in that framework simply continue on the chosen path of criminalization. Yet again, it is then not so clear why this criminalization path is originally chosen, for example, for environmental and insider trading issues, but not for others. It also does not explain why various proposals are made to improve private enforcement in the areas of consumer and competition law, but not in the areas of environment or insider trading.

A more plausible, albeit rather simple explanation probably concerns the division of competences within the European Commission. The various domains examined belong to competences of different directorates-general (DG) and it has been described in the literature that there is to some extent competition between those DG's and that collaboration and information exchange is in some cases lacking. ${ }^{227}$ Again, it would require a further detailed analysis of the law making process at EU level but it seems plausible that, for example, the environmental and market DG's had their mind strongly set on criminalization, largely ignoring private enforcement and developments that are taking place in that domain in the consumer and competition area, whereas DG's Sanco and Comp had apparently their minds more set on ways to improve private enforcement, and to some extent administrative enforcement, ignoring the potential of criminal enforcement. ${ }^{228}$ Once the minds of bureaucrats had been set on the necessity of a particular instrument, path dependency could further explain why it was difficult to change the route that was once

\footnotetext{
${ }^{225}$ See Pierre Legrand, European Legal Systems are not Converging, 46 INT'L \& COMPARATIVE L. Q. 52 (1996); Wolfgang Kerber \& Klaus Heine, European Corporate Laws, Regulatory Competition and Path Dependence, 13 EUR. J. OF L. AND ECON. 47 (2002); Anthony Ogus, The Economic Basis of Legal Culture: Networks and Monopolization, 22(3) OXFORD J. OF LEGAL STUD. 419 (2002).

${ }^{226}$ For details see the discussion supra section C III 2.

227 Les Metcalfe, Reforming the Commission: Will Organizational Efficiency Produce Effective Governance?, 38(5) J. of Cомmon Mкт. Stud. 817 (2000); Roger P. Levy, European Commission Overload and the Pathology of Management Reform: Garbage Cans, Rationality and Risk Aversion, 84(2) PUB. AdMIN. 423 (2006).

228 The names and competences of the individual DGs also keep changing.
} 
chosen. Although we do not have strong proof, we presume that this may explain the rather diverse picture of enforcement in EU law as it is summarized in table 1.

\section{Policy Conclusion: Towards a Coherent Approach}

In this respect, we can be relatively short and modest: Short, because our summary of the theoretical literature leads to a possible combination of different enforcement instruments in table 3 . At the same time, we should be modest, because we do realize that especially the rough summary in table 3 is not sufficiently balanced to capture complex realities. Tradingoff the various criteria in table 2 we provided a more balanced picture concerning the optimal combination of different enforcement instruments. At the same time, it also shows that it is probably not possible to suggest the use of just one instrument for one particular area, but that based on the criteria one will come to differentiated suggestions on combining various instruments in an optimal way.

In that sense, our suggestions concerning an optimal mix of instruments could, of course, be completed with issues we have not discussed in this contribution, like the possibility of using collective actions within private enforcement. To some extent, collective actions may as well, as we have indicated above, remedy some of the problems of classic private enforcement, like rational apathy following from the widespread nature of the damage, as public enforcement could. Hence, to the extent that collective actions would be stimulated this could, within the optimal mix, reduce the need for public enforcement. The Commission is more aware of the necessity of horizontal harmony regarding the matter of collective actions. The recommendation applies to various policy areas: Consumer and competition, but also environment and financial services and it is kept open for which other sectors it may be suitable. ${ }^{229}$

That is precisely the point of our paper: When developing enforcement instruments, it would be preferable to do this on the basis on the relative strengths of different instruments in the particular fields. We have provided the criteria that could be used which could lead to a more structural approach to enforcement in the future. We have shown which results this would suggest for the areas under investigation. The analysis could likewise be extended to other domains of EU policy.

\section{F. Conclusion}

The Article began by identifying the EU's competences for law enforcement in various policy areas. There is no such thing as a general competence for EU law enforcement. The provisions are, as a matter of fact, most pronounced with a view to criminal law with the respective treaty article. This article is applicable for basically any policy area. On private or

${ }^{229}$ See Recommendation. 
administrative law enforcement, the EU competences are less explicit. Most of what has been developed, however, for instance in the CJEU case law, again applies generally to any area of the law.

Next, the different use that was made of the legislative competences with a view to enforcement measures was illustrated in detail. Depending on the policy area under review the suggestions vary considerably. We do not necessarily find a pure reliance on one mechanism, but also attempt to mix enforcement mechanisms. The EU Commission's motivations differ according to the policy area. The EU's competences are indeed wide and horizontal enough to enable such a diverse picture. The question, therefore, emerges of whether the choices are justified with a view to a consistent pattern. As such, they look very inconsistent.

Now, it would obviously be comforting to know that there is an overarching logic in the EU's approach to enforcement. To test whether the differences are due to different sectorial needs is the next step that needs to be taken, which we will subsequently carry out. Let us provocatively say that the idea suggests itself that the different approaches could be due to some lack of a coherent enforcement policy in the EU-a missing horizontal approach that lacks a legislative rationale. ${ }^{230}$ We suspect that there is a lack of horizontal convergence, except for the context of collective redress where the EU has, however, not come any further than a recommendation.

The question we examined, next, in this Article is whether those different approaches to these different policy areas were justified, considering the economic approach to optimal enforcement mixes between private, administrative, and criminal enforcement in the light of a cost-effectiveness approach, for example, favoring the mechanism that can achieve a high level of compliance at lowest costs. Our finding was that there are deviations between the optimal mix of various enforcement approaches and the approach currently followed by the EU in various policy areas. The reasons for those divergences are not always very clear. We suggest that there is a lack of coordination within the European Commission. This may well be the most important reason for the diversification, which does not always make sense from an economic perspective. This is particularly true with a view to the use of the criminal law. Regarding private and administrative enforcement, EU action seems much more in line with the law and economics model.

Obviously, our analysis was limited to a rough sketch of private, administrative, and criminal enforcement and could and should be refined by looking deeper into the particular

\footnotetext{
${ }^{230}$ With the new Juncker Commission, the traditional restructuring of the DGs and their areas of competence has again taken place, http://ec.europa.eu/about/juncker-commission/structure/index_en.htm (last visited February 14, 2016).
} 
instruments used within those domains. This would allow us to come to refined conclusions on optimal mixes of particular instruments.

The EU will, in the coming years, undoubtedly increase its actions as far as regulating enforcement is concerned. The goal of our contribution was to indicate that it would be wise to strive for consistency in the way in which the EU will take further action in this domain in the future. As we have indicated, the law and economics literature with respect to optimal enforcement mixes may provide a useful tool to provide the necessary consistency in that respect. At the same time, we should be modest, because we do realize that especially the rough summary in table 3 is not sufficiently balanced to capture complex realities. Still, by attempting to trade-off the various economic criteria, we provided a more balanced picture concerning the optimal combination of different enforcement instruments. When developing enforcement instruments, it would be preferable to do this considering the relative strengths of different instruments in the particular fields, rather than on the basis of path dependency and the preferences within particular directorates of the European Commission. At the same time, our results also show that it is probably not possible to suggest the use of just one instrument for one particular area, but that based on the criteria one will come to differentiated suggestions on combining various instruments in an optimal way. 
